\title{
Intermodal Transportation of Spent Fuel
}

September 1983

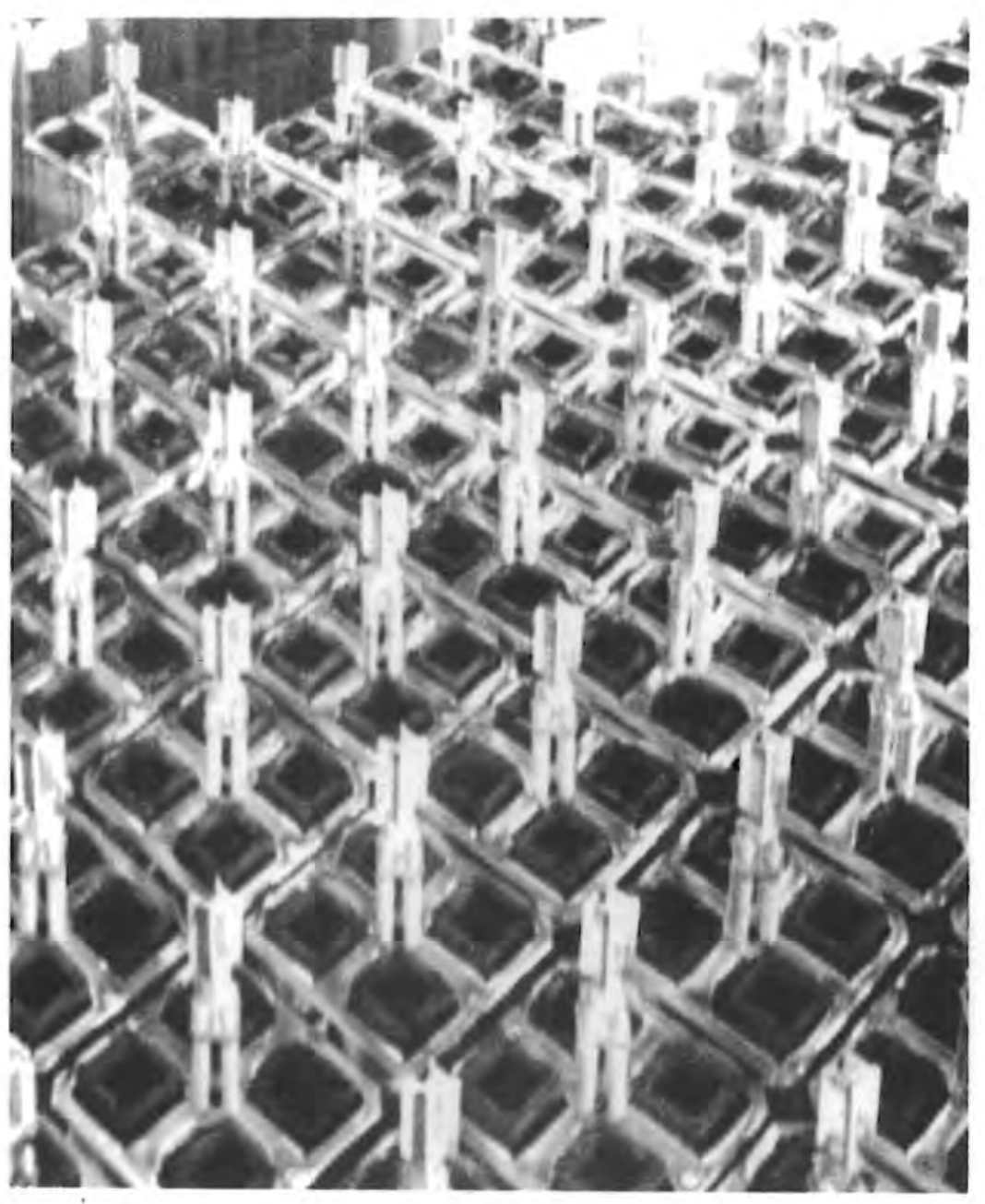

Prepared for the U.S. Department of Energy under Contract DE-AC06-76RLO

Pacific Northwest Laboratory Operated for the U.S. Department of Energy by Battelle Memorial Institute 


\title{
DISCLAIMER
}

This report was prepared as an account of work sponsored by an agency of the United States Government. Neither the United States Government nor any agency thereof, nor any of their employees, makes any warranty, express or implied, or assumes any legal liability or responsibility for the accuracy, completeness, or usefulness of any information, apparatus, product, or process disclosed, or represents that its use would not infringe privately owned rights. Reference herein to any specific commercial product, process, or service by trade name, trademark, manufacturer, or otherwise, does not necessarily constitute or imply its endorsement, recommendation, or favoring by the United States Government or any agency thereof. The views and opinions of authors expressed herein do not necessarily state or reflect those of the United States Government or any agency thereof.

\author{
PACIFIC NORTHWEST LABORATORY \\ operated by \\ BATTELLE \\ for the
}

UNITED STATES DEPARTMENT OF ENERGY

under Contract DE-AC06-76RLO 1830

\begin{tabular}{|c|c|}
\hline \multirow{2}{*}{\multicolumn{2}{|c|}{ Printed in the United States of America }} \\
\hline & \\
\hline \multirow{2}{*}{\multicolumn{2}{|c|}{$\begin{array}{l}\text { Available from. } \\
\text { National Technical Information Service }\end{array}$}} \\
\hline & \\
\hline \multirow{3}{*}{\multicolumn{2}{|c|}{$\begin{array}{l}\text { United States Depariment of Commerce } \\
5285 \text { Port Royal Road } \\
\text { Springfield, Virginia } 22151\end{array}$}} \\
\hline & \\
\hline & \\
\hline \multirow{2}{*}{\multicolumn{2}{|c|}{$\begin{array}{l}\text { NTIS Price Codes } \\
\text { Microfiche A01 }\end{array}$}} \\
\hline & \\
\hline \multicolumn{2}{|c|}{ Printed Copy } \\
\hline & Price \\
\hline Pages & Codes \\
\hline $001-025$ & $\mathrm{~A} 02$ \\
\hline $026-050$ & $\mathrm{~A} 03$ \\
\hline $051-075$ & $\mathrm{~A} 04$ \\
\hline $076-100$ & A05 \\
\hline $107-125$ & A06 \\
\hline $126-150$ & A07 \\
\hline $151-175$ & A08 \\
\hline $176-200$ & $A 09$ \\
\hline $201-225$ & A010 \\
\hline $226 \cdot 250$ & A011 \\
\hline $251-275$ & $\mathrm{~A} 012$ \\
\hline $276-300$ & A013 \\
\hline
\end{tabular}


INTERMODAL TRANSPORTATION

OF SPENT FIJEL

H. K. Elder

September 1983

Prepared for the

U.S. Department of Energy

Under Contract DE-ACO6-76RLO 1830

Pacific Northwest Laboratory

Richland, Washington 99352 
, 


\section{ABSTRACT}

Concepts for transportation of spent fuel in rail casks from nuclear power plant sites with no rail service are under consideration by the. U.S. Department of Energy in the Commercial Spent Fuel Management Program at the Pacific Northwest Laboratory. This report identifies and evaluates three alternative systems for intermodal transfer of spent fuel: heavy-haul truck to rail, barge to rail, and barge to heavy-haul truck.

This report concludes that, with some modifications and provisions for new equipment, existing rail and marine systems can provide a transportation base for the intermodal transfer of spent fuel to federal interim storage facilities. Some needed land transportation support and loading and unloading equipment does not currently exist. There are insufficient shipping casks available at this time but the industrial capability to meet projected needs appears adequate. 



\section{ACKNOWLEDGMENTS}

This work was initiated under a contract to the DOE Transportation Technology Center at Sandia National Laboratories.

Technical direction and guidance provided by Dr. George C. Allen, Sandia National Laboratories, and John G. DeSteese and William B. Andrews, Pacific Northwest Laboratory, greatly assisted this effort. 



\section{CONTENTS}

ABSTRACT

i i i

ACKNOWLEDGEMENTS

$\checkmark$

1.0 INTRODUCTION..................................... 1.1

1.1 BACKGROUND................................... 1.1

1.2 APPROACH................................... 1.3

2.0 SUMMARY...................................... 2.1

3.0 REGULATORY CONSIDERATIONS $\ldots \ldots \ldots \ldots \ldots \ldots \ldots \ldots \ldots \ldots \ldots \ldots \ldots \ldots \ldots \ldots \ldots$

3.1 UNITED STATES FEDERAL REGULATIONS .................... 3.1

$3.1 .1 \quad N R C$ Regulations........................... 3.2

3.1 .2 DOT Regulations.......................... 3.3

3.1 .3 ICC Regulations............................. 3.3

3.2 THE NUCLEAR WASTE POLICY ACT ...................... 3.3

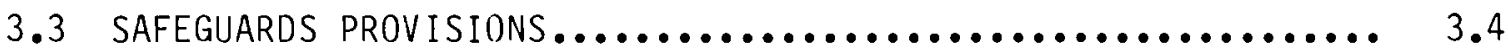

4.0 SPENT FUEL SHIPPING SYSTEMS.......................... 4.1

4.1 SPENT FUEL AND CASKS $\ldots \ldots \ldots \ldots \ldots \ldots \ldots \ldots \ldots \ldots \ldots \ldots \ldots \ldots \ldots \ldots \ldots . . \ldots . \ldots . \ldots$

4.1 .1 Spent Fuel................................ 4.1

4.1 .2 Spent Fuel Casks............................. 4.3

4.2 TRANSPORT SYSTEMS $\ldots \ldots \ldots \ldots \ldots \ldots \ldots \ldots \ldots \ldots \ldots \ldots \ldots \ldots \ldots \ldots \ldots \ldots$

4.2.1 Heavy Haul Truck Transport....................... 4.9

4.2.2 Rail Transportation........................... 4.9

4.2 .3 water Shipment............................. 4.14

4.2.4 Foreign Cask Transport Experience.................. 4.19

4.3 CASK HANDLING OPERATIONS AND EQUIPMENT ............... 4.20

4.3.1 Cask and Reactor Plant Interface.................. 4.20 
4.3.2 Intermodal Transfer............................ 4.24

4.3.3 Cask and Disposition Facility Interface............ 4.24

5.0 FUel SHIPMENT SCENARIOS............................ 5.1

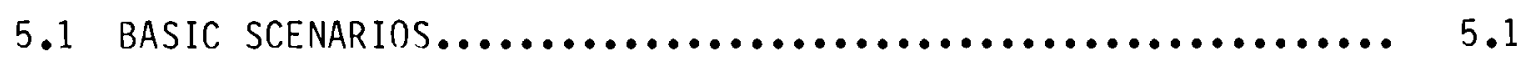

5.2 INTERMODAL TRANSPORT SEQUENCE DESCRIPTION............. 5.3

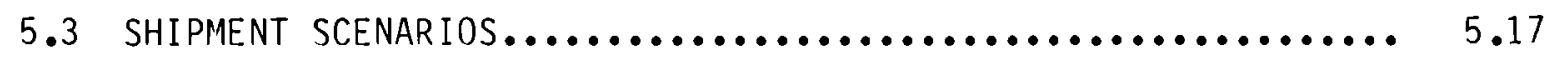

5.3.1 Rail Transport................................ 5.17

5.3 .2 Barge Transport.............................. 5.19

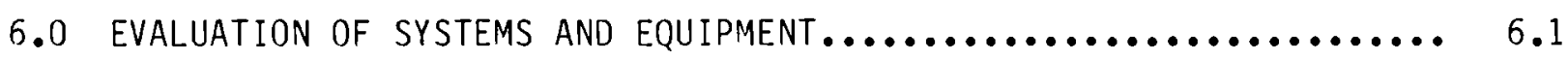

6.1 SPENT FUEL SHIPMENT SCENARIOS...................... 6.1

6.1.1 Heavy-Haul Truck to Rail Transport Scenario.......... 6.1

6.1.2 Barge to Rail Transport Scenario................. 6.4

6.1.3 Barge to Heavy-Haul Truck Transport Scenario......... 6.5

6.1.4 Summary of Spent Fuel Shipment Scenario Discussion.... 6.6

6.2 TRANSPORT SYSTEMS............................. 6.6

6.3 CASK HANDLING................................... 6.7

7.0 INTERMODAL EQUIPMENT AND RESEARCH NEEDS $. \ldots \ldots \ldots \ldots \ldots \ldots \ldots \ldots . . \ldots \ldots$

7.1 INTERMODAL EQUIPMENT NEEDS.$\ldots \ldots \ldots \ldots \ldots \ldots \ldots \ldots \ldots \ldots \ldots \ldots \ldots \ldots \ldots \ldots \ldots$

7.2 RESEARCH NEEDS............................... 7.5

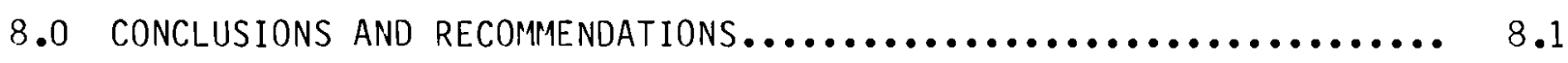

REFERENCES $. \ldots \ldots \ldots \ldots \ldots \ldots \ldots \ldots \ldots \ldots \ldots \ldots \ldots \ldots \ldots \ldots \ldots \ldots \ldots \ldots . \ldots \ldots$. 1 


\section{FIGURES}

4.1 Typical LWR Fuel Assemblies............................... 4.2

4.2 Transportation and Storage Cask........................... 4.8

4.3 IF-300 Cask and Rail Car.............................. 4.12

4.4 IF-300 Truck/Rail Transfer Equipment...................... 4.13

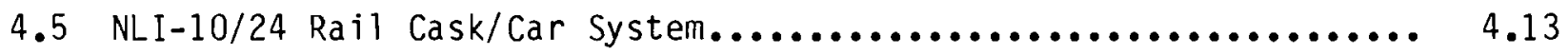

4.6 Waterways of the United States.......................... 4.16

4.7 Unloading 0perations Sequence at Fuel Disposition Facility....... 4.25

5.1 Basic Intermodal Transport Scenarios....................... 5.2

5.2 Generalized Intermodal Transport Sequence.................. 5.4

5.3 Floating Bridge Rol1-On/Rol1-Off Transferral Process........... 5.21

5.4. HHT Rol1-On/Rol1-Off Transferral Process.................... 5..21 


\section{$\underline{T A B L E S}$}

1.1 Reactors with Storage Space Requirements Through 1989.......... 1.2

2.1 Intermodal Equipment Requirements....................... 2.2

4.1 Current United States Rail Spent Fuel Cask Inventory............ 4.3

4.2 Characteristics of Spent Fuel Rail Casks in the U.S............ 4.4

4.3 Typical Cask Design Variations............................. 4.5

4.4 Characteristics of Rail Cars Used to Transport Nuclear Fuel...... 4.11

4.5 Ships Used to Transport Spent Nuclear Fuel................... 4.17

4.6 Spent Fuel Vessel Specifications......................... 4.18

4.7 Typical Steps for Loading the IF-300 Rail Car Cask............. 4.22

5.1 Basic Intermodal Transport Sequence Scenarios.................. 5.1

5.2 Intermodal Transport Sequence Data for Heavy-Haul Truck to Rail Baseline Scenario.................................... 5.5

5.3 Intermodal Transport Sequence Data for Barge to Rail Baseline Scenario.......................................... 5.9

5.4 Intermodal Transport Sequence Data for Barge to Heavy-Haul Truck Baseline Scenario....................................... 5.13

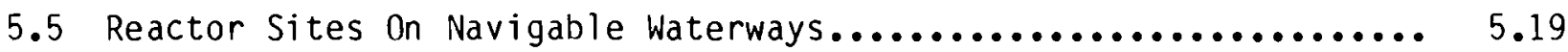

5.6 Advantages/Disadvantages of Barge Versus Separate Motor Vessel for Transport of Radioactive Material Packages..................... 5.22

6.1 Transport Cask Comparison.............................. 6.7

6.2 Spent Fuel Cask Turnaround Cycle......................... 6.8

7.1 Equipment Availability for the Heavy-Haul Truck to Rail Scenario.. 7.2

7.2 Equipment Availability for the Barge to Rail Scenario........... 7.3

7.3 Equipment Availability for the Barge to Heavy-Haul Truck Scenario......................................... 7.4

7.4 Intermodal Equipment Procurement Lead Times................. 7.6

8.1 Intermodal Equipment Requirements....................... 8.1 


\subsection{INTRODUCTION}

Many domestic nuclear power plants will exceed their projected onsite spent fuel storage capabilities beginning in the mid-1980s. Since neither reprocessing nor disposal capability will be available in the United States at that time, utilities must look for other ways to provide the needed additional storage space. The Nuclear Waste Policy Act of 1982 (NWPA) authorizes the U.S. Department of Energy (DOE) to provide limited amounts of federal interim storage (FIS) of commercial spent fuel. One of the objectives of the Cominercial Spent Fuel Management Program (CSFM) at the Pacific Northwest Laboratory $(P N L)(a)$ is to evaluate potential strategies for federal interim storage for spent nuclear fuel. One of the strategies being considered is the use of metal casks for dry storage of spent fuel at a DOE site. The NWPA requires that the $D O E$ be responsible for transportation of the spent fuel from commercial power plants to the DOE FIS site.

\subsection{BACKGROUND}

It may be safer and more economical to transport spent fuel in large casks. Compared to the use of current spent fuel truck casks, use of existing rail casks would reduce the amount of onsite handling at the FIS site and the offsite transportation requirements. Corresponding reductions in the cost and complexity of receiving and handling facilities at the FIS, in transportation costs, and in public and occupational radiation exposures would result. These factors are minimized if transportation can be made in even larger storage casks. However, use of storage casks for transportation has not been shown to be feasible at this time.

All large spent fuel transportation and storage casks are designed for transport by rail. However, many nuclear power plant sites are served only by truck at the present time. This report discusses regulatory and engineering considerations of utilizing intermodal transportation equipment to provide large cask pickup and delivery at sites without rail service. For the purposes

(a) Operated for the U.S. Department of Energy by Battelle Memorial Institute. 
of this study, potential intermodal transfers of spent fuel using storage casks or existing rail transportation casks are assumed to include heavy-haul truck to rail, barge to rail, and barge to heavy-haul truck.

A recent survey has indicated that 16 nuclear power plants will lose full core reserve by 1989. These plants, along with their access to rail routes, are shown in Table 1.1. Six of these plants are without rail service. These plants have the potential to ship 365 tonnes of PWR fuel to the FIS through 1989. If existing storage cask designs are used to ship unconsolidated fuel, up to 32 intermodal shipments would be required. IJse of existing rail casks with unconsolidated fuel would require at least 110 intermodal shipments.

TABLE 1.1. Reactors with Storage Space Requirements Through 1989

\begin{tabular}{ccc} 
Fuel Available & Rail Service \\
Reactor & For Shipment (MTU) & Availability \\
\hline
\end{tabular}

PWR

\begin{tabular}{lcl}
\hline Surry-2 & 102 & No \\
Surry-1 & 88 & No \\
Palisades & 33 & Yes \\
Turkey Point-3 & 58 & No \\
St. Lucie-1 & 69 & No \\
Millstone-2 & 81 & Yes \\
Trojan & 83 & Yes \\
Robinson-2 & 57 & Yes \\
Turkey Point-4 & 47 & No \\
Prairie Island-1 & 1 & Yes \\
BwR & & \\
Millstone-1 & 32 & Yes \\
Peach Bottom-2 & 32 & Yes \\
Pilgrim-1 & 1 & No \\
Lasalle-1 & 44 & Yes \\
Lasalle-2 & 46 & Yes \\
Peach Bottom-3 & 40 & Yes
\end{tabular}


The investigation documented in this report was initiated under a previous DOE program through the Transportation Technology Center at Sandia National Laboratories to recommend system alternatives to facilitate intermodal transportation of spent fuel from foreign nuclear power plants to the United States for storage. The scenarios for transportation, intermodal handling sequences, and assessments of equipment needs, however, are all generally applicable to domestic intermodal transportation of spent fuel. For this reason, this work was expanded to provide additional information on storage casks and was pub1 ished under the CSFM program.

\subsection{APPROACH}

The following activities are documented in this report, with the objective of identifying and evaluating alternatives needed to facilitate intermodal transportation of spent fuel:

- assess the requirements and availability of intermodal transport concepts and equipment

- determine whether transportation and transfer between modes can be accomplished with the existing available equipment

- describe the transport systems (i.e., the cask, transport equipment, and handling equipment) needed to assure that intermodal transfer of casks can be accomplished in the future.

The following intermodal transportation scenarios are evaluated:

- heavy-haul truck to rail

- barge to rail

- barge to heavy-haul truck.

These scenarios correspond to alternative modes of transportation from the reactor to the FIS site.

Five key study bases were established for this study. These study bases have an impact on the methods and operation of intermodal transport systems. Therefore, the bases and assumptions must be carefully examined before applying the results to a specific transport system and reactor facility. The key bases are: 
1. Equipment and transport methods used are those currently available.

2. The public must be protected from accidents involving cask movements.

3. Evaluation is based on real existing transport systems as much as possible.

4. Personnel involved in shipment are experienced in spent fuel transport.

5. Spent fuel transport systems and regulations are assumed to be based on 1982 regulations.

From these major study bases, specific bases and assumptions are derived for study areas and are presented in the report sections where they are used. The approach used in conducting this study is outlined by the following steps:

- describe the potential transportation scenarios in terms of generalized intermodal transport sequences (ITS)

- define and identify transportation activities along the ITS path

- identify concepts and equipment applicable to each scenario

- determine the availability and adequacy of components for the points on the ITS path

- identify hardware and technology needed to implement the ITS scenario as identified

- derive conclusions and recommendations for needs to implement the various intermodal transport systems analyzed.

The first step is to describe the transport system scenarios in terms of a generalized intermodal transport system (ITS). The ITS is defined by setting up a series of alternative transportation and storage modes connected by intermodal interfaces. This network connects the transport path from the fuel cask storage area, to the reactor and then to the storage site. The specific transportation activities along the ITS path are then identified, and concepts and equipment applicable to each particular scenario are identified. From this, the availability and adequacy of the components for the different scenarios can be determined, and the hardware and technology needed to implement the ITS 
scenario are identified. Conclusions and recommendations for needs to implement intermodal transport systems are provided based on the results of this study.

Regulatory considerations that must be taken into account when intermodal transport is involved are discussed in Section 3. Spent fuel transport (shipping) systems consisting of the casks, transport equipment, and handling equipment are described in Section 4 and the development of fuel shipment scenarios and evaluation of systems and equipment for those scenarios follows in Sections 5 and 6 . Finally, equipment and research needs are identified in Section 7 , and conclusions and recommendations are presented in Section 8 . 
.

.

. 


\subsection{SUMMARY}

Spent fuel storage strategies under consideration by the U.S. Department of Energy in the Commercial Spent Fuel Management (CSFM) program at the Pacific Northwest Laboratory(a) require the transportation of spent nuclear fuel from existing nuclear power plant sites to a federal interim storage or monitored retrievable storage location. One of the storage concepts currently under consideration includes large metal storage/transport casks that can only be moved by the rail transportation mode. Some nuclear power plants do not have adequate rail capacity to handle these large casks. This may necessitate the use of heavy-haul truck shipments to a railhead or seaport for transfer to the storage facility.

Three principal scenarios are considered: heavy-haul truck to rail, barge to rail, and barge to heavy-haul truck. These scenarios correspond to the alternative modes of transportation from a nuclear power plant to a barge port or to a railhead.

Fuel shipment scenarios are described in terms of an intermodal transport sequence (ITS). The ITS is defined as a series of transportation and transfer links and storage modes starting at the origin of the empty cask, proceeding to the reactor site and continuing to the storage site. Alternate transportation modes (e.g., heavy-haul truck, train or barge) and transfer (air pallet, crane, portable dollies) can be used for different links in the ITS.

The variables that can influence the schedule of fuel shipments, transport time and the equipment and manpower availability are compared on the basis of transit time. The various scenarios are based on the assumption that one-third of a PWR reactor core consisting of 72 fuel assemblies would be transported annua1ly.

Table 2.1 summarizes the equipment needed to facilitate intermodal shipments of spent fuel for the three baseline scenarios.

(a) Operated for the U.S. Department of Energy by Battelle Memorial Institute. 
TABLE 2.1. Intermodal Equipment Requirements

\begin{tabular}{|c|c|c|c|}
\hline \multirow[b]{2}{*}{ Item } & \multicolumn{3}{|c|}{ Scenario } \\
\hline & HH Truck/RaiT & Earge/Rajl & Barge/HH Truck \\
\hline Equipment Skids & $x$ & $x$ & $x$ \\
\hline Cask Lifting Device & $x$ & $x$ & $x$ \\
\hline $\begin{array}{l}\text { Dedicated Transport Barges/ } \\
\text { Dedicated Small Ship }\end{array}$ & & $x$ & $x$ \\
\hline Cask Handling Equipment & $x$ & $x$ & $x$ \\
\hline Heavy Haul Truck Trailers & $x$ & & $x$ \\
\hline Air Pallets & $x$ & $x$ & $x$ \\
\hline Tie-down Equi pment & $x$ & $x$ & $x$ \\
\hline $\begin{array}{l}\text { Transport/Storage Cask/ } \\
\text { Rail Cask for Long-Cooled Fuel }\end{array}$ & $x$ & $x$ & $x$ \\
\hline Roll-on, Roll-off Equipment & $x$ & $x$ & $x$ \\
\hline Rail Car for Casks 0ther than IF- & 300 & $x$ & $x$ \\
\hline
\end{tabular}

The implementation of intermodal spent fuel transportation requires further research and development in several areas:

- Individual reactors should be reviewed to determine the specific logistics of each case.

- Alternative equipment for intermodal transport should be evaluated to determine their feasibility.

- Intermodal transfer capability may be needed for casks other than the General Electric Company, IF-300 storage cask. (The GE IF-300 cask is designed for intermodal transport capability.)

- Cask availability should be verified.

- Use of barge or small ship should be studied.

- Cost of the various modes should be estimated.

- Availability of a commercial small ship for fuel transport should be investigated.

- Investigation of casks for long-cooled fuel is recommended. 
- Investigation of the feasibility of using transport/storage casks is required.

- Availability of commercial barges should be investigated. 
. 


\subsection{REGULATORY CONSIDERATIONS}

Primary reliance for safety in transporting irradiated (spent) nuclear fuels is provided by shipping casks that contain the spent fuel. Irradiated nuclear fuel has been safely transported since the mid-1940s in various kinds of shipping casks. Different cask designs were developed because of the variety of U.S. Atomic Energy Commission (AEC), military, research, and commercial nuclear reactors in service. Experience gained in the design and use of these casks, plus comprehensive Nuclear Regulatory Commission (NRC) and Department of Transportation (DOT) regulations (10 CFR 71 and 49 CFR 173), have led to the present generation of shipping casks. These regulations are described in this section.

Overseeing the safety aspects of transporting radioactive materials in the United States is the responsibility of the DOT and NRC. State and local requirements generally consist of auxiliary regulations that pertain to transportation routes and highway load limits or regulations that require additional safety measures.

Regulations issued by the NRC and DOT overlap to some degree. A memorandum of understanding, issued in 1966 and revised in 1973 (DOT and AEC 1973), generally delineates the authority of the DOT as the setting of standards for inarking, labeling, shipping safely (radiation levels, temperatures, etc.), regulating shippers and carriers, and approving shipping containers for radioactive inaterials as defined by Code of Federal Regulations, Title 49, Part 173.393 (49 CFR 173.393) (CFR 1975).

The Office of Hazardous Materials of DOT is designated, in 49 CFR 173.393, as the competent authority in the United States responsible for administering International Atomic Energy Agency (IAEA) transport regulations (IAEA 1973). DOT requirements for moving foreign-made packages in the United States are also listed in 49 CFR 173.393.

\subsection{UNITED STATES FEDERAL REGULATIONS}

Major regulations for transporting radioactive materials are set forth in Code of Federal Regulations, Title 10, Part 20 (10 CFR 20) "Standards for 
Protection Against Radiation;" Part 71 in (10 CFR 71), "Packaging of Radioactive Materials for Transport and Transportation of Radioactive Material Under Certain Conditions;" and in Code of Federal Regulations, Title 49, Part 173 (49 CFR 173) "Shippers--General Requirements for Shipment and Packagings" (1975 Edition).

The packaging and shipping requirements for transporting radioactive materials are based on the quantity, type, and fissile characteristics of the isotopes being shipped. Recause of the presence of plutonium and other toxic isotopes, irradiated nuclear fuel is transported under the most restrictive rules.

Shipments of fissile material are classified as either Fissile Class I, II, or III, as defined by 49 CFR 173.396. Spent fuel shipments are rated in the most restrictive class--Fissile Class III, which requires special equipment and handling procedures to ensure nuclear criticality safety during shipinent.

Federal safeguards regulations (10 CFR 73.6b) exempt special nuclear materials that are not readily separable from other radioactive materials and that have a dose rate $>100 \mathrm{rem} / \mathrm{hr}$ at a distance of three feet when there is no intervening shielding. Requirements for physical protection of spent fuel in transit are outlined in 10 CFR 73.37. The requirements include route planning, advance notification, avoidance of heavily populated areas, and use of armed escorts.

\section{$3.1 .1 \quad$ NRC Regulations}

The general NRC criteria for packaging and shipping radioactive materials are given in 10 CFR 71 Subparts $B, C$, and $D$. Because of the quantity of radioactive material designated for irradiated fuel shipments, spent fuel casks must be designed to meet hypothetical accident conditions as described in 10 CFR 71 with no loss of containment capability. To show that a cask design will meet the conditions of 10 CFR 71, a detailed safety analysis report (SAR) for the cask must be submitted to the NRC. Approval of this SAR and compliance with handling rules allows shipinent of the package by all surface transportation modes. 


\subsubsection{DOT Regulations}

DOT regulations for transportation of radioactive materials are given in 40 CFR 170-179. These regulations set the criteria for radiation levels, surface temperatures, surface contamination levels, bill of lading information, labeling, placarding, shipper certification, accident response, general packaging, and foreign shipments into and from the United States.

DOT regulations specific for different shipping modes are contained in "Carriage by Rail," (49 CFR 174); "Carriage by Aircraft," (40 CFR 175); "Carriage by Vessel," (40 CFR 176); and "Carriage by Public Highway," (49 CFR 177). These rules generally differ in shipping requirements. Like NRC, DOT package requirements are the same for all surface modes of transportation.

3.1.3 ICC Regulations

The Interstate Commerce Commission (ICC) has the principal economic regulatory authority over nuclear transportation. The ICC regulates the rates, charges, and conditions of truck, rail, and barge line services operating in interstate commerce. ICC regulations define three types of carriers:

1) private carriers, which transport their own goods and are exempt from ICC regulations; 2) contract carriers, which selectively transport other people's goods and are subject to limited ICC regulation; and 3) common carriers, which transport goods for the general public in accordance with ICC certificates of public convenience and necessity. The latter ICC regulation is directly applicable to intermodal transportation.

\subsection{THE NUCLEAR WASTE POLICY ACT}

The Nuclear Waste Policy Act of 1982 (NWPA) provides "... for the establishment of a federally owned and operated system for the interim storage of spent nuclear fuel at one or more..." federal facilities. Such facilities are currently labeled as federal interim storage (FIS) facilities. The NWPA also states that "the Federal fovernment has the responsibility to provide... (limited) capacity for interim storage of spent nuclear fuel for civilian... reactors that cannot reasonably provide adequate storage capacity (at the) reactors when needed to assure the continued operation of such reactors." The 
NWPA requires that the DOE be responsible for transportation of the spent fuel from commercial power plants to the DOE FIS site.

The FIS is intended to be short-term, and is to be discontinued no later than three years after opening of a federal facility for disposal or monitored retrievable storage of these materials. It is currently planned that a federal repository will be in operation by the year 1998, and monitored retrievable storage, if needed, would be in operation by the year 1998 if the repository is delayed. It is currently expected that one or more utilities will need interim storage of spent fuel in the 1984 to 1987 time period (DOE 1983). The NWPA establishes a 1900-MT linit for interim storage. Thus, federal interim storage could be implemented as early as 1985 and emptied and shut down as late as 2001 .

Some of the interim storage concepts under consideration involve dry storage of spent fuel in air or in inert gas atmospheres. One of the leading concepts for interim storage is to store spent fuel in large metal storage casks. Current cask designs allow up to 24 PWR fuel assemblies or 52 BWR assemblies (or about double these amounts if the fuel is consolidated and canned) to be placed in each storage cask.

These storage casks may also become licensed for cross-country transportation, but that is not expected to be accomplished until after 1986. Thus, the spent fuel will be transported in existing casks that are designed and licensed for transportation, and will need to be transferred to the storage casks at the FIS site.

\subsection{SAFEGUARDS PROVISIONS}

Safeguards provisions have been developed by the NRC and DOT to address problems related to possible terrorist action against spent fuel shipinents. The following requirements apply to shippers and carriers: routing preapproval, embargo urban areas, communications/security guards (escorts), vehicle immobilization provisions, and procedures to cope with threats and sabotage. These regulations impose severe restrictions on the allowable routings, and simultaneously, incur considerable additional costs due to the need for additional equipment and additional personnel to safeguard the material en 
route. As a result, the utilization of trucks, which have been the simplest mode of shipment, may present the most complicated logistic and handling problems in the United States. 
.

. 


\subsection{SPENT FUEL SHIPPING SYSTEMS}

The intermodal transport systems considered in this study (i.e., cask, transport equipment, handling equipment) provide the means of shipping spent LWR nuclear fuel in approved and licensed shipping containers from reactor storage basins to a federal interim storage (FIS) site. Transport systems used to ship spent fuel are described in this section. The characteristics of the spent fuel, spent fuel casks and transport storage casks are described in Subsection 4.1. Following the cask descriptions, transport equipment for moving spent fuel is described in Subsection 4.2. Cask handling systems for transferring the spent fuel casks between transport modes are discussed in Subsection 4.3 .

\subsection{SPENT FUEL AND CASKS}

When nuclear fuel can no longer sustain a chain reaction at economic power levels, it is considered to be spent and removed from the reactor. About onethird to one-fourth of an LWR fuel load is removed each year and replaced by fresh fuel. Spent fuel is stored temporarily under water in reactor basins. Transportation in heavy, shielded spent fuel casks is required when interim storage is desired away from the reactor.

\subsubsection{Spent Fuel}

The fuel currently used in LWRs is uranium dioxide $\left(\mathrm{UO}_{2}\right)$ in which readily fissionable uranium-235 $\left({ }^{235} \mathrm{U}\right)$ has been enriched from its natural abundance $(\sim 0.7 \%)$ to 3 or $4 \%$. LWR fuel rods consisting of $\mathrm{UO}_{2}$ pellets encased in either stainless steel or zirconium alloy (Zircaloy) tubes are assembled into bundles (fuel assemblies) in a square array. Each rod is spaced and supported by grid structures and end pieces. Two types of LWR fuel are in use in the United States reactors. Although similar in design, the fuel assemblies for pressurized water reactors (PWRs) and boiling water reactors (BWRs) differ somewhat in configuration as shown in Figure 4.1. They also differ in size and in the quantity of fuel contained. 
B. Typical fuel Rod

A. Typical PWR Fuel Assembly

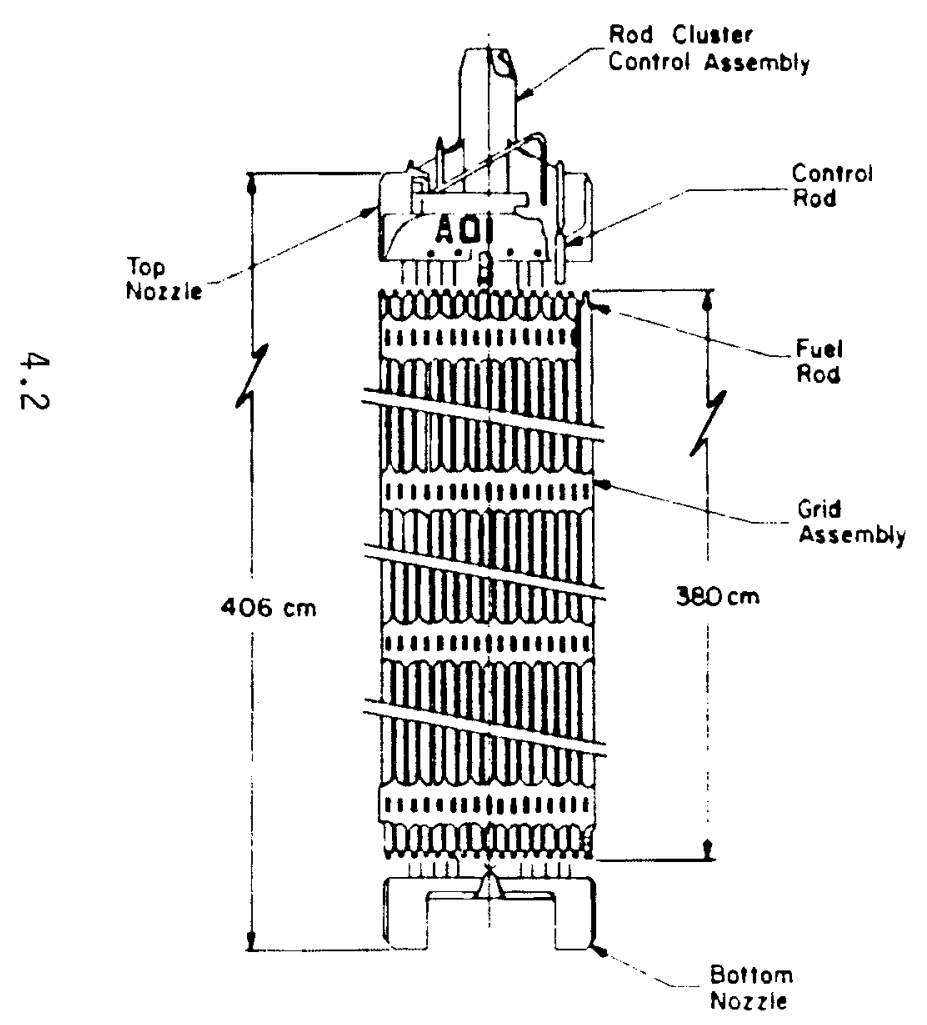

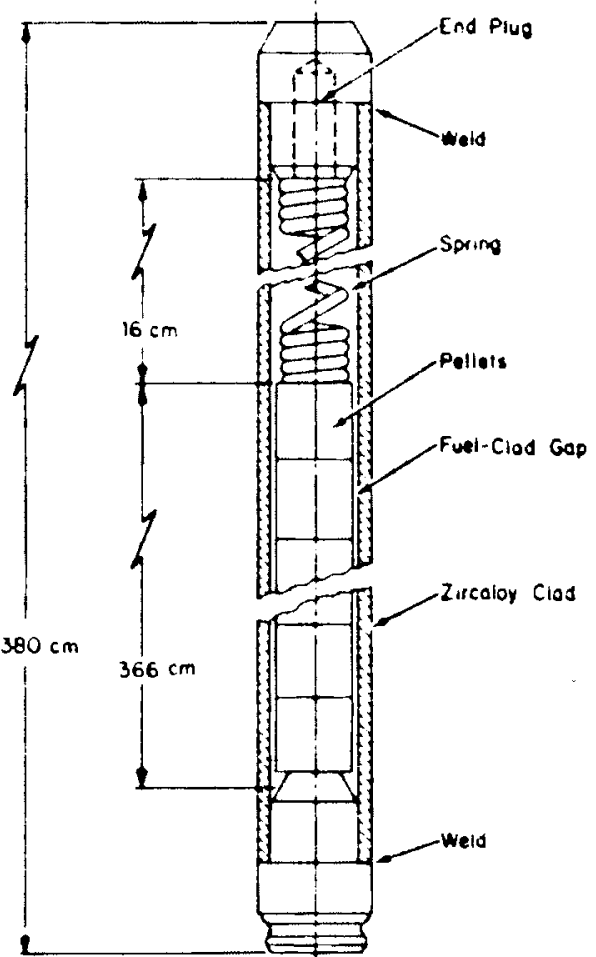

FIGURE 4.1. Typical LWR Fuel Assemblies
C. Typical BWR Fuel Assembly

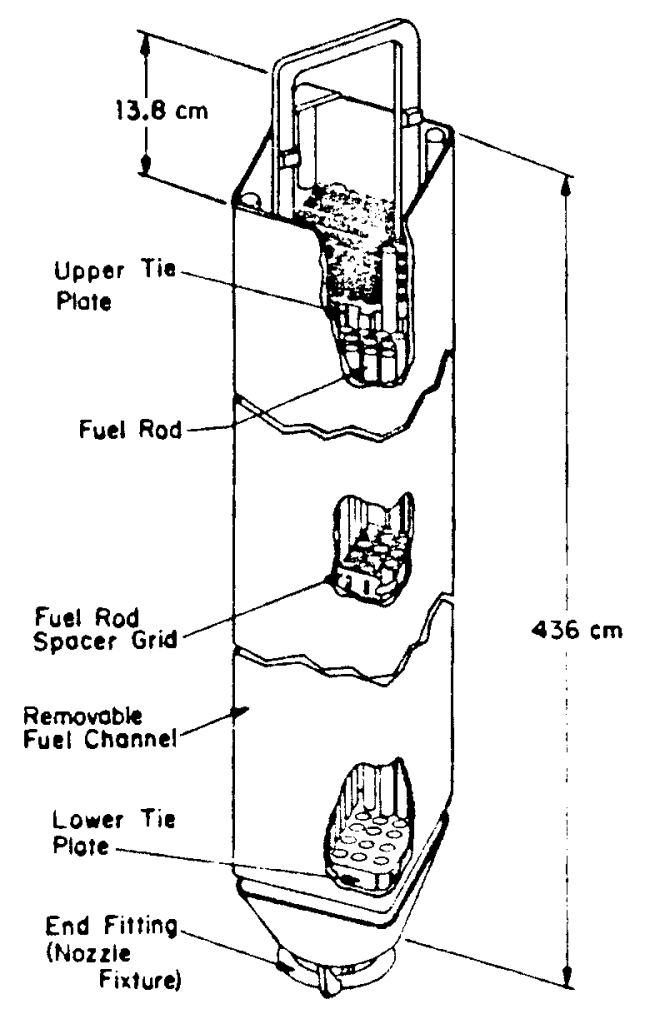




\subsubsection{Spent Fuel Casks}

All spent LWR fuel transported in the United States is currently shipped in heavily shielded casks by truck or rail. Shipping casks are generally massive, having a low payload-to-total weight ratio, and are expensive to operate having daily use charges of approximately $\$ 800 /$ day for legal weight truck casks and up to $\$ 4,500 /$ day for rail casks. Truck casks weigh 23 to 36 metric tons (MT) (25 to 40 tons) when fully loaded and will normally accommodate one to three PWR fuel assemblies or two to seven BWR fuel assemblies. Currently designed rail casks weigh up to 95 MT (107 tons) when fully loaded and can transport 7 to 12 PWR or 18 to 32 BWR fuel assemblies. Transport/storage casks weigh 100 MT when fully loaded and can transport 9 PHR or 25 BWR fuel assemblies.

Barge shipments have not been used in the United States primarily because of the current adequacy of truck and rail capacity. The availability of suitable water routes and the lack of adequate docking facilities may impede this development. In the future, domestic barge shipments may be favored as a result of route restrictions placed on overland transportation (Winsor, Faletti and DeSteese 1980).

4.1.2.1 Existing Inited States Casks

Current rail shipping casks are shown in Table 4.1. The rail casks listed are the IF-300, TN-12 and NLI-10/24. For this report, discussion will be 1 imited to the rail casks since truck casks are not anticipated to require

TARLE 4.1. Current United States Rail Spent Fuel Cask Inventory(a)

\begin{tabular}{|c|c|c|}
\hline Mode 1 & Type & Number \\
\hline IF-300 & Rail & 4 \\
\hline$T N-12^{(b)}$ & Rail & 0 \\
\hline NL I $-10 / 24$ & Rail & 2 \\
\hline Total & & 6 \\
\hline
\end{tabular}

(a) From Anderson 1978a. and Daling 1983.

(b) The TN-12 is currently under development; no casks are available. 
intermodal handling. Table 4.2 lists the characteristics of these principal cask designs. Table 4.3 lists the design variations found in existing casks.

TABLE 4.2. Characteristics of Spent Fuel Rail Casks(a) in the U.S.

\begin{tabular}{|c|c|c|c|}
\hline & $\begin{array}{l}\text { General Electric Co. } \\
\text { San Jose, Cal i fomia } \\
\text { IF-300 }\end{array}$ & $\begin{array}{c}\text { Transnuclear, Inc. } \\
\text { White Plains, New York } \\
\text { TN-12 }\end{array}$ & $\begin{array}{l}\text { NL Industries, Inc. } \\
\text { Nuclear Division } \\
\text { Wi Imington, Del aware } \\
\text { NLI-10/24 }\end{array}$ \\
\hline Transport Mode & OWT/Rail & Rail & Rail \\
\hline $\begin{array}{l}\text { Capital Cost } 1978 \\
\$ \text { millions }\end{array}$ & 3.5 to 4.0 & 5.5 & 4.5 \\
\hline $\begin{array}{l}\text { Daily Use Chg. } \\
\$ \text { thousands }\end{array}$ & 3.5 & 4.4 & 3.6 \\
\hline $\begin{array}{l}\text { PWR/BWR Assembl ies/ } \\
\text { Cask }\end{array}$ & $7 / 18$ & $12 / 32$ & $10 / 24$ \\
\hline Loaded Cask weight iT & 63.5 & 97 to 105 & 91 \\
\hline $\begin{array}{l}\text { Gross Vehicle weight } \\
\text { MT }\end{array}$ & 120 & 136 to 147 & 160 \\
\hline $\begin{array}{l}\text { Cavity Dimensions } \\
\text { (dia } x \text { length) om. }\end{array}$ & $95 \times 460$ & $122 \times 460$ & $115 \times 460$ \\
\hline $\begin{array}{l}\text { Overall Dimensions } \\
\text { (dia } x \text { length) o. }\end{array}$ & $162 \times 530$ & $250 \times 675$ & $260 \times 570$ \\
\hline Gamma Shield Material & Uranium & Steel & Lead \\
\hline Neutron Shield & Water & Organ ic & Water \\
\hline Cavity Coolant & water ${ }^{(b)}$ & Air & Helium \\
\hline $\begin{array}{l}\text { Cask Exterior } \\
\text { Surface }\end{array}$ & Corrugated & Copper Fins & $\begin{array}{l}\text { Stainless } \\
\text { Steel Fins }\end{array}$ \\
\hline US NRC License & Yes & No & Yes \\
\hline Number of Casks in U.S. & 4 & 0 & 2 \\
\hline $\begin{array}{l}\text { Approximate Nurber } \\
\text { of Trips/Reactor } \\
\text { Year, BWR/PWR }\end{array}$ & 9/9.3 & $5 / 5.5$ & $6.7 / 6.5$ \\
\hline
\end{tabular}

(a) Fram Anderson 1978a and Daling 1983.

(b) These casks may be shipped dry (air) under low heat load conditions. 
TABLE 4.3. Typical Cask Design Variations(a,b)

Design Feature

Shielding (gamma)

Shielding (neutron)

Cavity Coolant

Heat Rejection

Closure Heads

Lifting Trunnions

Fuel Capability

Basket Internal

Designs

Drain Systems

Lifting Yokes

Impact Limiters

Surface Contamination Protection

Varying Fuel Length
Variations

Steel; steel-lead; steel-depleted uranium; steel-lead-depleted uranium

Water; borated water; solid hydrogenous material

Water; air; evacuated air; helium

Finned, corrugated surface; smooth outer surface; auxiliary cooling (water-air)

Single; double

Two in upper region; four in upper region; upper and lower region trunnions

Both PWR and BWR fuel; dedicated solely to PWR; dedicated solely to BWR

Extruded aluminum; fabricated steel structure; poison sleeves and rods; leaker fuel cans

Bottom drain; side draining; top vent

Single yokes; redundant (double yokes)

Integral with the cask; removable - remain on vehicle; removable - removed from vehicle; doughnut-shaped, top-hat shaped; etc.

None; contamination barriers (plastic and metal)

Different closure head designs, basket length modifications; dedicated casks for long fuel accomplished by axial lengthening of the cask body

(a) From Anderson 1978a.

(b) Other variations include cavity lengths; gasket types (steel polymeric 0 -rings, etc.); valve connections; use of safety valve, rupture disc, zero release; personal barrier (clamshell opening; horizontal opening; and barrier directly removed from the car). 
Rail casks have the advantage of carrying a greater payload than truck casks. For a given amount of spent fuel, rail transportation reduces the number of shipments, ( 5 to 9 shipments per reactor-year depending upon the cask design), labor and radiation doses received by workers. As shown in Table 4.1, the current inventory of rail casks in the United States is 5 .

\subsubsection{Future Spent Fuel Casks}

Existing spent fuel casks are designed for safe shipment of spent fuel that has been cooled 150 to 180 days. These casks have cooling fins and other heat dissipation devices, and in some cases, auxiliary cooling systems to remove the decay heat load. Current cask designs have features that are not necessary for transporting spent fuel that is cooled 4 years or longer. They also require extra handling and care during loading, unloading, and shipping. The casks meet D0T radiation limits with spent fuel cooled about 0.5 years. When filled with spent fuel cooled 4 years or longer, the radiation levels are at least a factor of 6 less than the DOE radiation limits.

New cask programs have been announced by Transnuclear, Inc., Nuclear Assurance Company, and Edlow International Inc. (Anderson 1978a). Several of these cask developinent efforts are addressing the prospect of transporting long-cooled fuel. Industry is, therefore, already anticipating future needs despite the current under-use of existing casks.

Future casks specifically designed for greater than 4-year cooled spent fuel can reduce costs, increase payloads and operating efficiency, and decrease turnaround times compared with the casks designed for 0.5-year cooled spent fuel. These casks for long-cooled fuel may not require auxiliary heat removal systems and probably would not need fins to dissipate heat. The deletion of these heat dissipation features may tend to reduce the cost of fabrication and testing of the casks. A simplified exterior cask structure could decrease decontamination effort and loading and unloading times. In addition, less shielding would probably be needed to maintain compliance with existing external radiation standards. 


\subsubsection{Transport/Storage Casks}

The concept of interim storage of spent nuclear fuel in casks that are also utilized as transportation containers has been adopted for general use in the Federal Republic of Germany (Dierkes et al. 1980). A similar concept is being funded by the Department of Energy in the United States (Nuclear Waste News 1982).

Major features of the reference cask and detailed portions of the facility important to decommissioning are described in this section. The Gesellschaft fur Nuklear-Service (GNS) cask design is utilized as a fundamental component of the reference cask.

The cask is shown in Figure 4.2. The design engineering was executed by GNS of West Germany. Heavy biological shielding is provided by the 400-mmthick nodular cast iron wall structure. Neutron shielding is contained within longitudinal borings in the cast material, thereby facilitating heat transfer from the fuel to the outer cooling fins by the iron directly. The cooling fins are cast together with the body. All openings in the cask are clustered at the top. Each opening is provided with double barriers suitable for leak detection. The fuel storage cavity is plated to provide a surface that is corrosion resistant, and the exterior surface is coated with decontaminable paint. The radiation dose at the cask surface is less than $20 \mathrm{mrem} / \mathrm{hr}$ when filled with fuel.

It is postulated that the cask is loaded with spent fuel in the reactor storage pool. After closing and fastening the first cover, water is evacuated from the cask cavity. The dried storage cavity is filled with helium at less than one atmosphere. The cask is removed from the pool, a second cover is sealed to the top, and the space between covers is evacuated and filled with helium to about 1.2 atmospheres. The lid seals are metallic.

The cask is transported from the reactor site to the FIS storage area where it is lifted upright and unloaded from the transport vehicle. A third and final lid is applied that incorporates a pressure transducer. The space between the second and third lid is evacuated and filled with helium at high pressure. The integrity of the seals is monitored in the control room by the pressure transducer indications of any inward or outward helium leakage. 

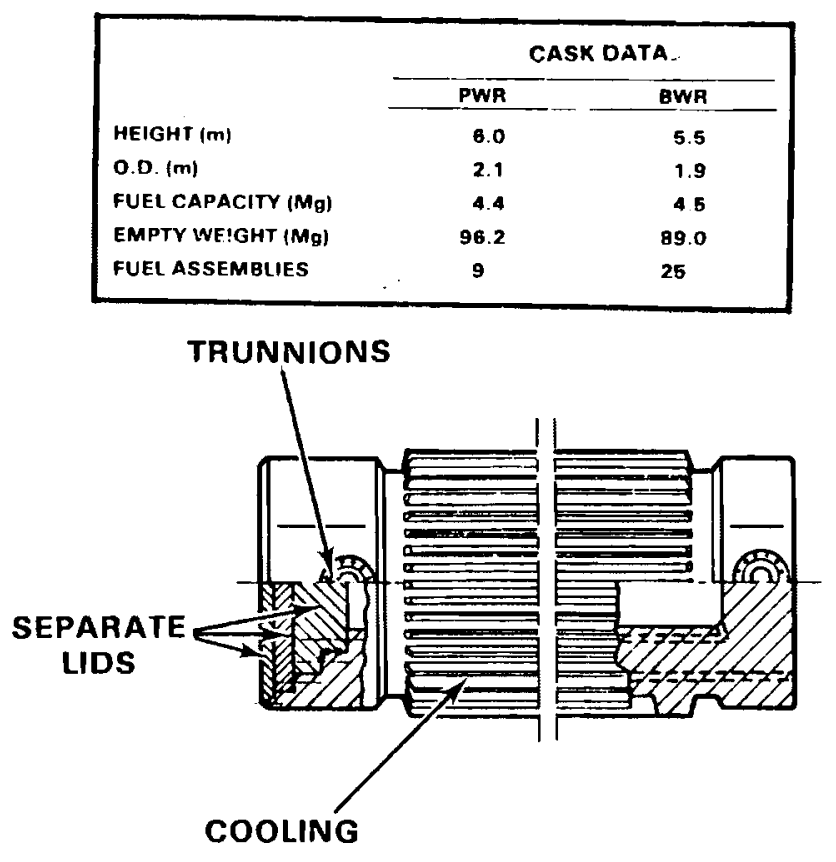

PLAN VIEW OF CASK LID

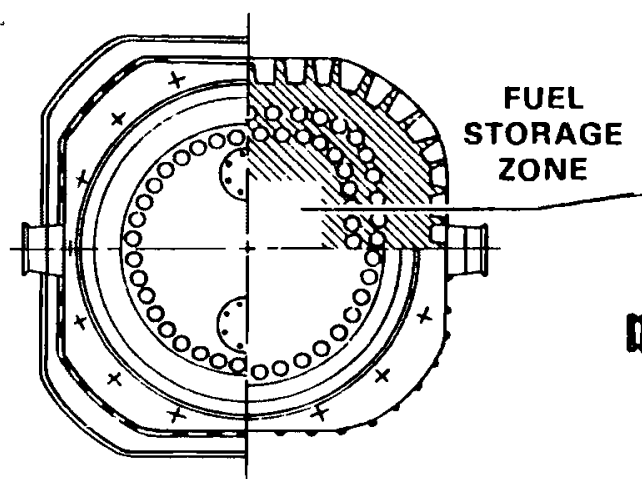

SECTION VIEW

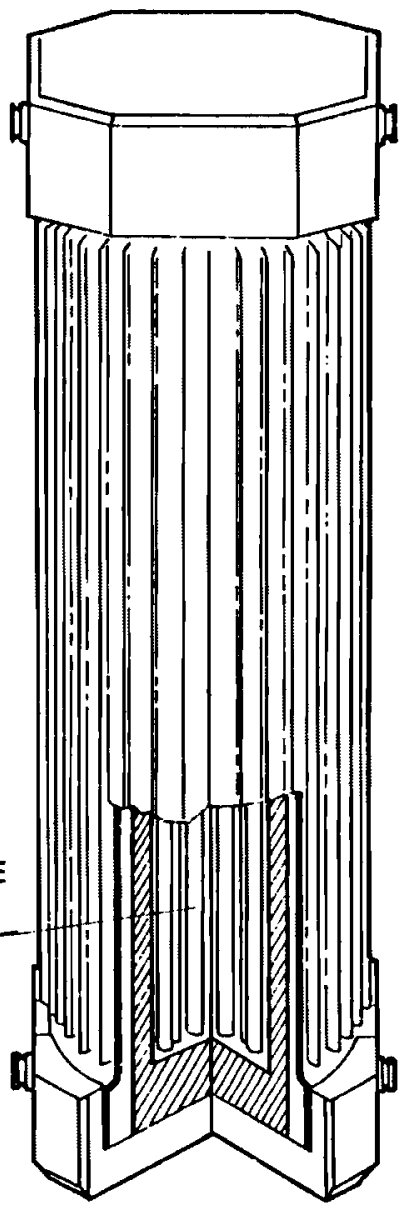

PERSPECTIVE

FIGURE 4.2. Transportation and Storage Cask 


\subsection{TRANSPORT SYSTEMS}

Existing transport systems that can be used for movement of spent fuel from reactors to a storage site are described below.

\subsubsection{Heavy-Haul Truck Transport}

Auxiliary truck transport equipment is available. The trucks themselves present few problems--tractors are available in substantial numbers, and lead times are relatively short for delivery of new equipment. Truck transport is implemented through the use of trucking firms or motor carriers that haul freight owned by another party. Common carriers provide transportation services to the public in general.

Interstate common carriers are subject to the economic regulations of the Interstate Commerce Commission (ICC). To transport interstate, a common carrier must have its specific services certified by the ICC. These certified carriers are also known as regulated or authorized carriers.

A number of motor carriers are involved in transporting nuclear materials. The scope of services performed by each carrier must be in strict compliance with its individual ICC-approved operating authority. A number of common carriers provide transport services for one or more areas of the nuclear industry.

\subsubsection{Rail Transportation}

Railroads are the primary means for transporting commodities in the United States. With few exceptions, the railroads serve the nation as common carriers who provide their services to all shippers. These services are offered under published tariff rates. The railroads' tariff rates and services are subject to control by the ICC.

Rail transport of spent nuclear fuel is similar to other heavy loads routinely transported, including large loads of hazardous nonradioactive materials. Some routes are not available because of clearance problems, track conditions and other local problems. Certain restrictions on the transport of nuclear materials may be imposed by states or local authorities. Some shippers are also requiring the use of special trains for transport of spent fuel, which can increase the cost significantly. 


\subsubsection{Rail Car Compatibility with Existing Railroads}

Existing and proposed rail casks, including cars, range from $115,000 \mathrm{~kg}$ $(255,000 \mathrm{lb})$ to $160,000 \mathrm{~kg}(350,000 \mathrm{lb})$ with even larger cask systems being planned. While the rail cars and casks used in the shipment of spent fuel represent heavy units, they are not unusually heavy. New rail cars put into service in the United States recently have been in the range of 105,000 to $140,000 \mathrm{~kg}$ gross weight. A check of the weight limitations for the United States railroads (DOE 1978C) shows $120,000 \mathrm{~kg}$ to be the most cormmon linitation for the major railroads with some routes going up to $145,000 \mathrm{~kg}$ for 4 -axle cars. Comments obtained from a few of the major railroads concerning the movement of a 160,000 kg gross weight car range from: 1) it would be no problem on a 6-axle car, to 2) the engineering department would have to decide. One railroad lists $140,000 \mathrm{~kg}$ as its maximum weight even for a 6 -axle car.

Potential transportation problems involve the question of route availability for the larger rail casks and cars. Each railroad involved in the movement of the cask would need to be contacted so they could accept the movement on their lines. The larger cask could be so limited in its movements that some routes would be unavailable because of weight and clearance problems. The smaller cask and rail car appears to pose no special weight problems on class 1 railroads.

Rail transport of large casks will probably need very detailed planning to be used effectively. The shipper and the railroads will have to work closely to minimize circuitous routing of this type cask.

\subsubsection{Rail Equipment}

While the rail casks and cars used to ship spent fuel represent heavy equipment, they are not unusually heavy. Most new 4-axle chlorine tank cars going into service have a capacity of 14,000 gallons, or 130,000 1b (82 MT), and a total weight in excess of 100 MT $(240,000$ 1b). Over 10,000 shipinents of chlorine are made in these cars each year. New 4-axle hopper cars have a gross weight of 120 MT $(263,000 \mathrm{lb})$. These cars are used routinely in a high-utilization unit train service. Typical locomotive units weigh between 112-180 MT $(250,000$ and 400,000 1b) and are supported on 4 or 6 axles. 
Presently, two basic rail car types are used to transport spent fuel: the GE 4-axle flatcar and the NLI 6-axle flatcar. The characteristics of these cars and their loads are shown in Table 4.4 .

TABLE 4.4. Characteristjçs of Rail Cars Used to Transport

\begin{tabular}{|c|c|c|c|c|}
\hline & $\begin{array}{c}\text { Tare We ight } \\
\text { lb (MT) } \\
\end{array}$ & $\begin{array}{c}\text { Container and } \\
\text { Load Weight } \\
\text { Ib (MT) }\end{array}$ & $\begin{array}{c}\text { Spent Fuel } \\
\text { Capacity } \\
\text { 1b (MT) } \\
\end{array}$ & $\begin{array}{c}\text { Total Weight } \\
\text { lb (MT) } \\
\end{array}$ \\
\hline Aar $(I F-300)$ & $75,500(34)$ & $182,000(83)$ & $7,150(3.25)$ & $257,500(117)$ \\
\hline NLI Car (NLI-10/24) & $130,000(59)$ & $218,870(100)$ & $9,965(4.52)$ & $349,500 \quad(159)$ \\
\hline
\end{tabular}

(a) From Loscutoff et al. 1977.

The IF-300 cask is normally transported by rail on a 100-MT capacity 4-axle flatcar. The equipment skid functions as a unitized pallet for the cask and cooling equipment. During shipment the skid sits directly on the bed of a slightly modified standard 100-MT capacity flatcar. The IF-300 cask and rail car are shown in Figure 4.3.

As an intermodal cask, the IF-300 can be transported by heavy haul truck (for short distances). For ease of overweight truck transportation, the IF-300 cask skid is designed to be directly connected to wheel assemblies with hydraulic goosenecks such as those used by most hauling firms specializing in heavy loads. The cask can be transferred from rail car to truck by use of an end ramp at the rail siding. This is illustrated in Figure 4.4 .

The transport system for the NLI-10/24 spent fuel shipping cask, which has a fully loaded weight of $160,000 \mathrm{~kg}$ (see Table 4.2 ), consists of a specially designed rail car with the cask tie-down arrangement built into the car frame. An arrangement drawing of the rail system for the NLI-10/24 is shown in Figure 4.5 . 


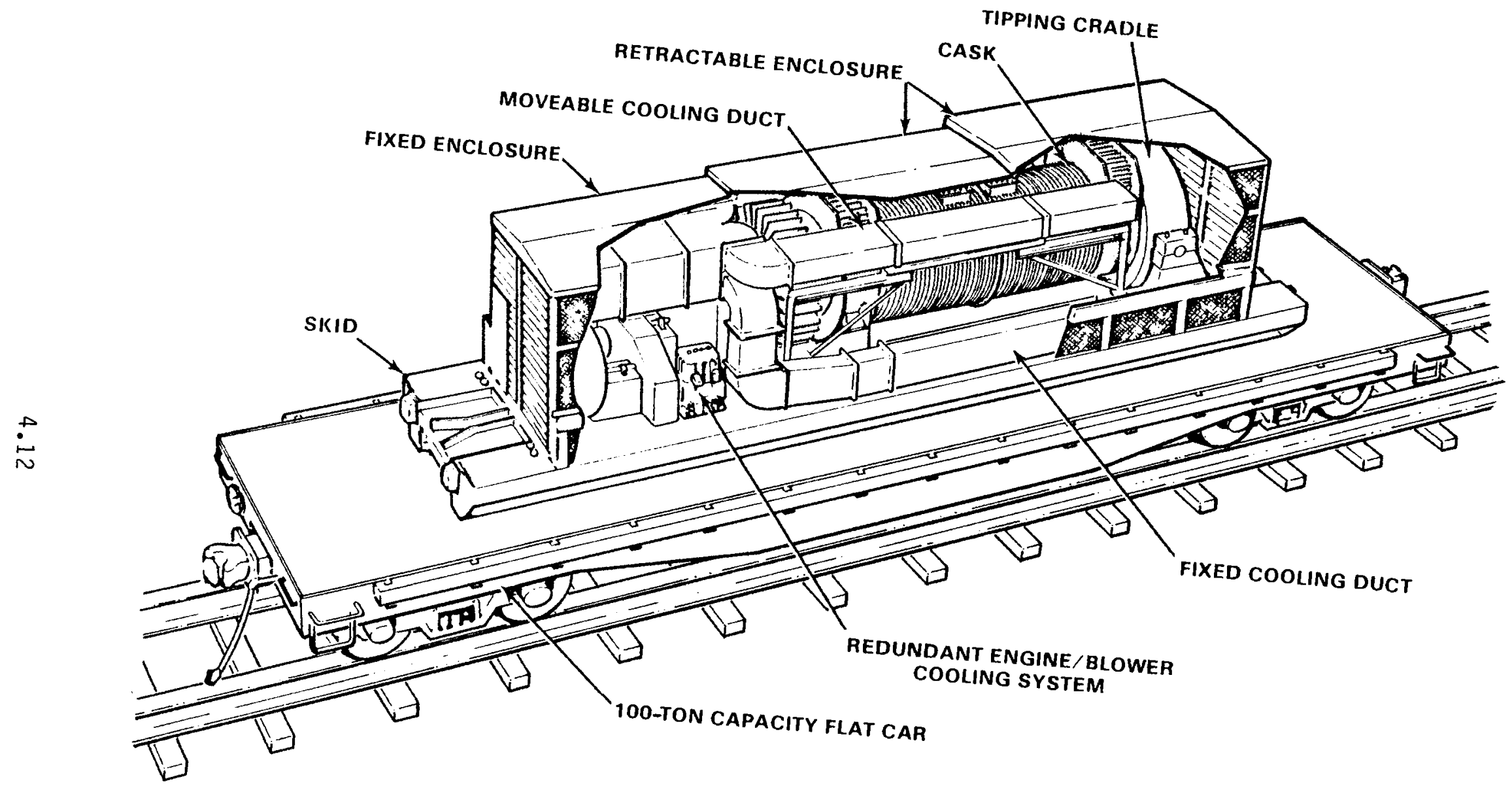

FIGUJRE 4.3. IF-300 Cask and Rail Car (Winsor, Faletti and DeSteese 1980) 


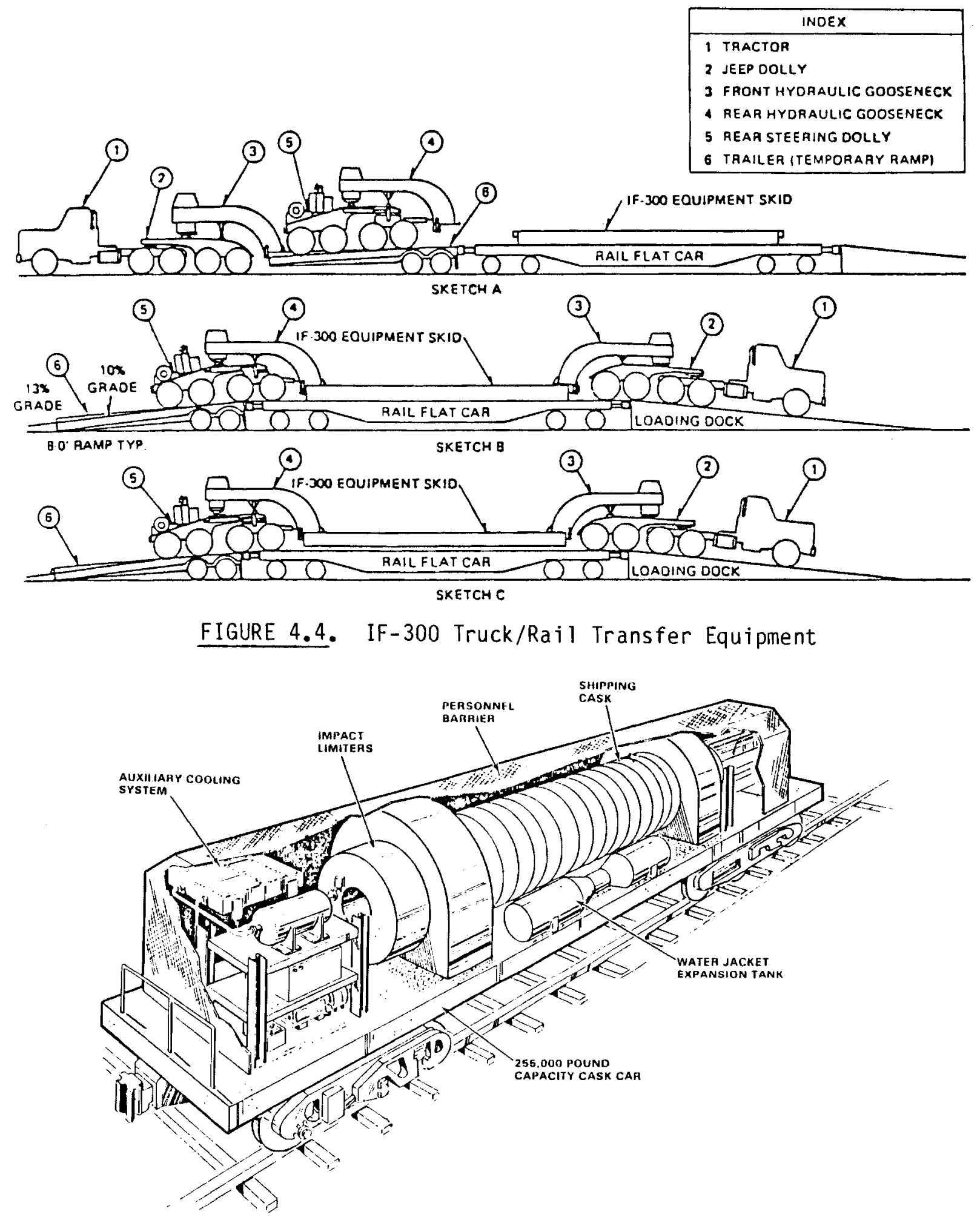

FIGURE 4.5. NLI-10/24 Rail Cask/Car System 
The rail car is equipped with redundant cask cooling systems that are used to lower in-transit cask and fuel temperatures to facilitate cask cooldown and unloading operations. The rail car-mounted cooling system is a closed circulating water loop consisting of a pump and a water-to-heat exchanger in series with cooling channels located on the cask inner shell. The system is normally run on forced convection with power supplied to the pump and heat exchanger fan by a diesel generator.

Under normal transport conditions, a personnel barrier completely covers both cooling system packages as well as the cask. The personnel barrier is an expanded aluminum sheet on an aluminum frame.

\subsubsection{Water Shipment}

A large portion of the existing reactor plants were built without the capability of shipping by rail. In many cases, the distance to the nearest rail site is as much as $24 \mathrm{~km}$. In addition, there has been a considerable ongoing conflict between the shippers (the nuclear power plant owners) and the carriers (the railroad owners) regarding costs and the relative safety of the shipments. This disagreement between the utilities and railroads has resulted in virtually no rail shipments of commercial power reactor spent fuel over the last eight years.

Rail casks and transport/storage casks described previously could be used to transport spent fuel on barges or small ships. Rail casks can be mounted on weight-spreading devices on the decks of barges and transport ships. Both ships and barges are equipped for roll-on and roll-off facilities that could be used to transport overweight trailers. Transoceanic shipments of spent fuel have been made in the holds of dedicated ships provided with load-spreadiny devices and equipment. Legal weight truck casks have been shipped to the United States in cargo vessels when the Innited States port was near the destination of the fuel.(a)

The British have gained experience in the transport of spent nuclear fuel since the mid-1950s. Shipments have been made from most areas of the world to

(a) Primarily, about 50 shipments destined for DOE's Savannah River Plant (DOE 1978b). 
the United Kingdom. Shipments have been made from Japan, Australia, India, South Africa, Canada, and the Mediterranean area and from various European countries. Most of the early shipments were transported either on deck or in a hold compartment of ordinary cargo ships (Kavanaugh and Shimoyama 1976).

Recent shipping service has used containerized shipping. However, standard containers are unsuitable for the heavy loads of spent-fuel casks, and container ships are therefore unsuitable. Since conventional cargo ships are on variable routes and schedules, present shipments of spent fuel casks have required exclusive use of a suitable ship acquired by charter, purchase, or new construction.

For the water transport of LWR oxide fuel, it is possible to carry the fuel with no ancillary equipment if the fuel is carried as deck cargo. When casks are transported in holds, the removal of heat becomes a crew-comfort problem. The Japanese have developed cooling equipment for use in the holds of ships carrying spent fuel (Kavanaugh and Shimoyama 1976).

\subsubsection{Water Transportation Routes}

The navigable waterways of the United States (see Figure 4.6) cover a total length of approximately 29,000 miles. Of this length, about 16,000 miles are usable by vessels requiring operating depths of 9 feet or more (Best et al. 1977). These deep waters are generally uninterrupted by shallows and encompass most of the Atlantic and Pacific seaboards, the Gulf Coast, the Mississippi River system and the Columbia-Snake River system in the State of Washington. With the exception of the Columbia-Snake River system, navigable inland waterways do not exist in the United States west of the Missouri river. Also, deep navigable waterways are not generally found between the western slopes of the Appalachian mountains and the Atlantic coastal regions.

The nuclear industry has used water transportation to move heavy and large items such as reactor pressure vessels and steam generators for many years. Studies concerning movement of spent fuel by barge were initiated in the early 1970 s. 


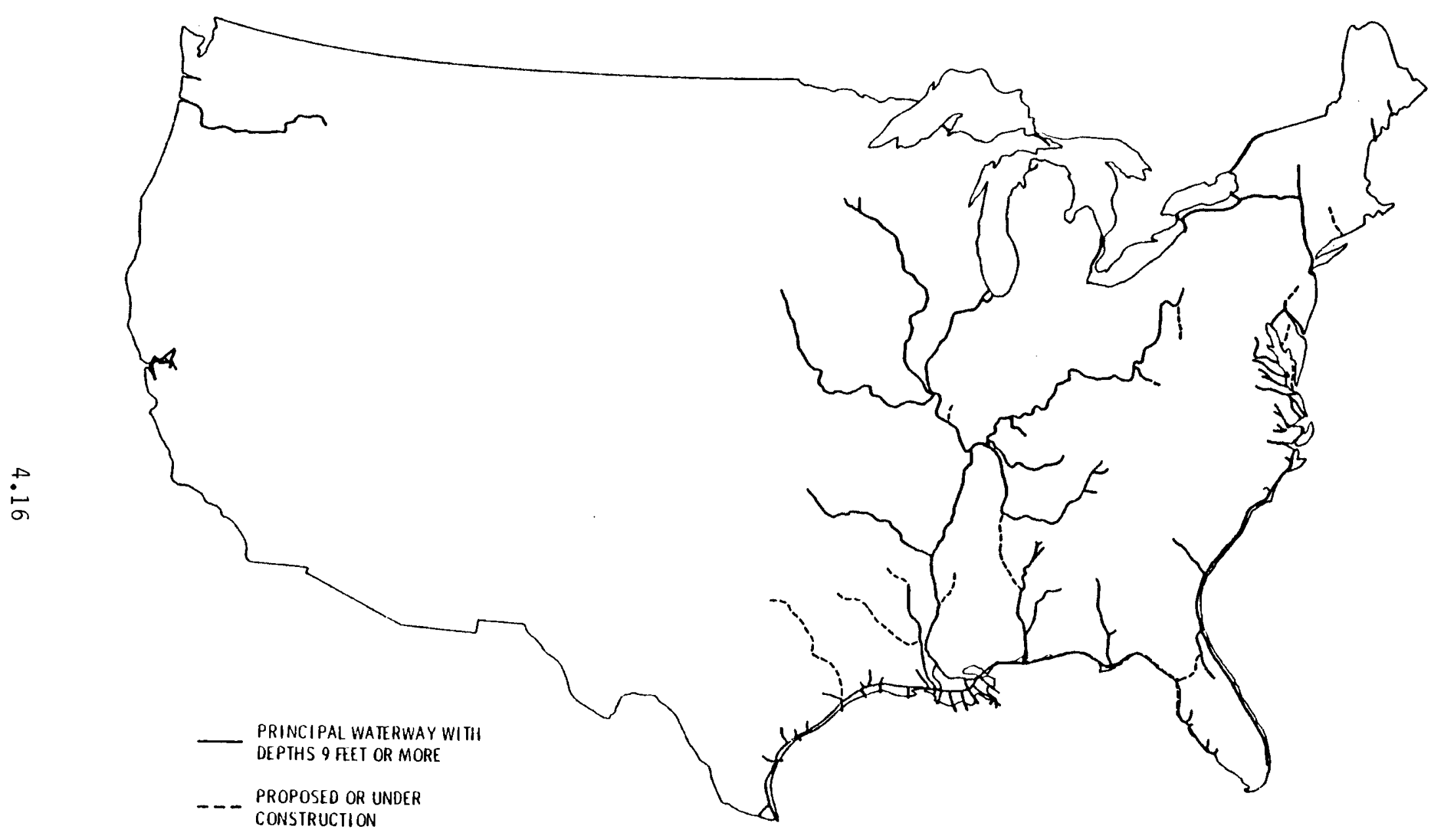

FIGURE 4.6. Waterways of the United States 


\subsubsection{Barge Equipment}

A typical steel construction class A, AA hull barge measuring $72 \mathrm{ft} 6$ in. by $43 \mathrm{ft} 6 \mathrm{in}$. by $10 \mathrm{ft} 9 \mathrm{in}$. was assumed in this study. The deck is $\mathrm{flat}$ and the hull partitioned into as many as 18 separate water tight compartments. Cross flooding pipes and tank interconnection hatches can be opened to provide symmetrical stability of the barge. This barge is large enough to carry 2 casks end to end. The deck is suitable for loads up to 10 tons per square foot, which will handle large casks. The installation of rails for roll-on roll-off service can be done on most barges.

\subsubsection{Marine Transport Equipment}

As an example of equipment available, ships that have been used for the transport of spent fuel overseas (Italian and Japanese) are listed in Table 4.5 .

TABLE 4.5. Ships Used to Transport Spent Nuclear Fuel (a)

\begin{tabular}{|c|c|c|c|c|c|}
\hline Ship Name & Owner & Service & $\begin{array}{c}\text { Dead Weight } \\
\text { of Vessel } \\
\text { (tons) } \\
\end{array}$ & $\begin{array}{l}\text { Capacity } \\
(M T U) \\
\end{array}$ & Fuel \\
\hline Stream Fisher & $\mathrm{BNFL}^{(b)}$ & $\begin{array}{l}\text { Italy to } \\
\text { UK }\end{array}$ & 1000 & 14 & Magnox \\
\hline Pool Fisher & BNFL & $\begin{array}{l}\text { Italy to } \\
\text { UK }\end{array}$ & 1500 & 20 & Magnox and $0 x i d e$ \\
\hline Lever Fisher & BNFL & $\begin{array}{l}\text { Japan to } \\
\text { UK }\end{array}$ & 3000 & 30 & Magnox and Dxide \\
\hline Pacific Fisher & BNFL & $\begin{array}{l}\text { Japan to } \\
\text { UK }\end{array}$ & 3000 & 45 & Magnox and $0 x i d e$ \\
\hline $\begin{array}{l}2 \text { More in } \\
1977-78\end{array}$ & BNFL & $\begin{array}{l}\text { Japan to } \\
\text { UK }\end{array}$ & 3000 & 45 & Magnox and $0 x i d e$ \\
\hline Hinoura-llaru & Japan $(c)$ & Japan Seas & 1290 & 14 & Magnox and $0 x i d e$ \\
\hline
\end{tabular}

(a) From Kavanaugh and Shimoyama (1976); Aoki and Ikeda (1978); and Mori (1978).

(b) Owned by British Nuclear Fuels Limited (BNFL).

(c) Owned by Japanese Government. 
The Japanese have developed a specialized sea-going carrier for spent fuel (Mori 1978). Table 4.6 gives the specification and details of the vessel as an example of the state-of-the-art in marine vessels for transporting spent fuel.

TABLE 4.6. Spent Fuel Vessel Specifications

\begin{tabular}{lr}
\multicolumn{2}{c}{ Vessel Specifications } \\
\hline Gross Tonnage (tons) & 1,290 \\
Length Overall (m) & 77.5 \\
Length (between perpendiculars) (m) & 72.0 \\
Depth (to upper deck) (m) & 5.85 \\
Depth (to erection deck) (m) & 7.75 \\
Designed Full Load Draft (m) & 4.20 \\
Full Load Service Speed (knots) & $\sim 11$ \\
Main Engine Power (hp) & 2,500 \\
Number of Casks & 17 \\
Crew Complement: & 1 \\
Officers and Crew Owners & \\
Owners & \\
Radiation Supervisor &
\end{tabular}

A special double hull provides protection in the event of a collision. The sides and the deck are reinforced with steel plates to absorb the force of the collision. The ship's sides have longitudinal bulkheads to minimize flooding. The ship is provided with transversals for safety against foundering even if the longitudinal bulkhead is damaged and the center is flooded. The ship is built with a double bottom and has enough depth to secure the casks from damage and minimize flooding.

The ship is stable enough not to exceed $25^{\circ}$ of heel angle during usual navigation. The ship will remain stable in the event of damage to the outer side-plates that results in flooding of the two subdivisions partitioned with transversals. The ship is fitted with refrigeration equipment and air cooling equipment to keep the temperature below $38^{\circ} \mathrm{C}$ in the cargo holds. Two cooling 
units composed of a recirculation pump and a heat exchanger are provided for the cask water cooling systems.

To prevent movement of the casks in the cargo holds, Excellox-3A casks are secured by bolts, and $\mathrm{Hz}-75 \mathrm{~T}$ casks are secured by wedges and hooks. These devices are strong enough to withstand $45^{\circ}$ rolls, pitching of $10^{\circ}$ and $1 \mathrm{G}$ acceleration.

\subsubsection{Foreign Cask Transport Experience}

Foreign cask intermodal transport experience that is applicable to this study is included here. Casks have been shipped from various reactor sites to reprocessing plants in the United Kingdom by 1) direct loading to a charter ship at the site, 2) road transport to the nearest port for intermodal loading to a charter ship, or 3) loading onto a rail car that is routed directly to England by barge.

Definite technical and economic advantages result from minimizing intermodal changes. Transfer from road to rail or sea transport requires the use of an expensive, heavy-lift crane and careful surveillance of tie-down equipment after the transfer. For truck transport operations, local contractors provide the tractor to haul the semi-trailer. When this creates problems, a contractor is used from the country through which the longest stretch of the trip takes place. For instance, a Spanish contractor may deliver a loaded semi-trailer to the Spanish border; then a French contractor takes over for a long haul to a port on the north coast of France. The trailer crosses on a roll-on, roll-off ferry with special storage and tie-down arrangements. On reaching the United Kingdom, a British contractor completes the journey. The coordination of these changes with three contractors crossing two frontiers and the channel demands a considerable expenditure of organizational effort.

Transport to the United Kingdom necessarily involves a sea journey. Three main types of transport have been:used:

1. charter ship or barge

2. rail ferry and rail to the plant site

3. roll-on, roll-off ferry across the channel and by road to the plant. 
The trend in Europe is towards heavy rail casks. Future French nuclear plants will use large-capacity casks. weighing over 100 MT that require rail transport (LeNoc and Bertonneu 1977). Light casks transported by road will be reserved in the future for cases where geographical and logistics conditions indicate a substantial advantage or requirement for truck transportation. If a reactor is not connected to a rail system, unless intermodal capability exists, such as the IF-300, problems may be encountered in transferring heavy casks by road to a suitable rail head where a special crane is required to make the transfer.

When power stations are not served by a rail system, shipping by rail requires the building of a transshipment station and the use of a special trailer or semi-trailer vehicle between this station and the plant. This equipment is currently available; however, cask turnaround time is increased.

\subsection{CASK HANDLING OPERATIONS AND EQUIPIIENT}

Casks must conform to handling requirements at the reactor, fuel storage basins, shipping docks, intermodal transfer points, and spent fuel disposition facilities. Spent fuel casks are generally shipped with the major axis of the cask in a horizontal position. Casks must have lifting lugs for the cask handiing cranes to move them to a vertical position at the unloading basin and at the disposition facility. The cask should be designed with a clean surface to minimize decontamination efforts.

Cask handling operations are discussed below for, the various interfaces in the intermodal transport sequence (ITS). These are: 1) cask and reactor facility interface, 2) intermodal transfer points in the ITS, and 3) cask and terminal facility interfaces. Cask handling operations at the storage location are similar to those at the other ITS locations.

\subsubsection{Cask and Reactor Plant Interface}

The different layout and operations of spent fuel handling facilities may create problems in handling a cask of given design. Provisions must be made to store protective devices and to wash road dirt from the cask. A yard tractor 
will probably be necessary for shuttling rail cars around the plant. A potential problem for many plants could be in the airlock/vehicle bay design. The vehicle must fit inside, allow the doors to be closed, and allow lateral movement of the vehicle since some plants do not have sufficient lateral crane travel to erect and lay down the cask on the vehicle. The main crane capacity and clearance are also potential problems or restrictions to the use of rail casks. Based on existing data and planned rail casks (Best et al. 1977) the minimum requirements for handling these casks are:

1. crane capacity of 70 tons for the smaller G.E. IF-300 cask, 100 tons for the NLI-10/24 cask (without crush pad) and up to 125 tons for the larger storage/transport casks.

2. vehicle loading area clearance heights range from $33 \mathrm{ft}$ for the G.E. cask to $40 \mathrm{ft}$ for the others

3. clearances necessary for movement from the loading/unloading area to the fuel pool ranged from $20.5 \mathrm{ft}$ for the G.E. cask to $28 \mathrm{ft}$ for the others. An area which needs special attention is the cask loading area in the spent fuel pool. Sufficient area must be available for the cask-yoke assembly, including space for engagement/disengagement of the yoke and seismic restraints; the pool bottom must be able to support the cask weight. The most restrictive area, especially for the larger rail casks, is the pool depth in the cask loading area. Some plants may be restricted to using the G.E. cask and some are restricted to a maximum loading height of $18 \mathrm{ft}$, (assuming $10 \mathrm{ft}$ of water above an assembly). These plants can accommodate current rail casks but may not acconmodate casks of greater length without providing sufficient water level for shielding above the fuel assembly.

Rail casks require special cooldown equipment for both routine and emergency cooling. Facilities and equipment for sampling the cask's fluids must also be provided. Another potential problem area is the decontanination facility, especially in the plants where the loaded cask must be moved to an adjacent facility to be prepared for shipment. This can be a very time-consuming operation that will significantly affect the cask turnaround time. 
Handling procedures for loading a rail cask (IF-300) are shown in Table 4.7. These procedures are specific to the cask systems shown, but could be applied generally to most existing casks.

TABLE 4.7. Typical Steps for Loading the IF-300 Rail Car Cask(a)

A - Prepare

1. Receive and inspect cask at the reactor Inspect for shipping damage

2. Remove cask from transport vehicle Unlock and open enclosures

Move cooling air ducts to extended position

Remove valve box covers and attach lifting yoke to cask

Lift cask and transport to wash-down area

3. Prepare cask for loading fuel assemblies

Fill cask with water and remove closure nuts

Wash cask exterior surfaces

Place cask in fuel handling pool

Remove closure and take it to gasket inspection

B - Load--Unload

4. Load fuel into cask

Handle bundles one at a tine

Verify identification of each bundle

C - Dispatch

5. Remove cask froin fuel pool

Put spray ring in place

Lower closure through spray ring onto cask

Engage lifting yoke and lift cask from pool

Install some head bolt nuts when cask is up to surface

Spray cask with high-pressure water as removed from pool

Set cask down on decontamination pad

6. Prepare cask for shipment

Install closure nuts and torque in sequence

Pressure test the cask

Flush pool water froin cask and adjust water level

Monitor temperature and pressure of cask hourly

Sample cask water one hour after flushing and before removal to car

Analyze samples and extrapolate activity to 100-hour concentrations

Decontaminate cask exterior to shipping release guidelines

7. Ship cask

Move cask to rail car

Remove trunnions, install tie-downs and valve box covers

Reposition and activate cooling system

close and lock enclosures 


\section{TABLE 4.7. (Contd)}

7. Ship cask (contd)

Complete required check lists, surveys, bill of lading

Dispatch rail car to storage facility

8. Receive and inspect cask at storage facility

Identify shipment from bill of lading and material transfer information Unlock and open enclosures, record cooling system information

Perform radiological and smear surveys

9. Remove cask from transport vehicle

slide cask enclosures back

Record cask temperature readings

Shut down cooling system and extend air ducts

Remove valve box covers and cask tie-down pins

Install lifting trunnions and attach lifting yoke to cask

Lift cask and transport to wash-down area

10. Prepare to unload fuel

Connect flush water piping

Sample first water discharged from lower fitting

Flush primary coolant to low activity waste collection

Wash cask exterior surfaces

Loosen closure nuts in sequence

Place cask in fuel storage pool

Remove closure and take to gasket inspection

11. Unload fuel from cask and store in racks

Handle bundles one at a time

Verify identification of each bundle

Install handles on PWR bundles

12. Remove cask from unloading pool

Lower closure onto cask

Put split spray ring into place

Engage lifting yoke and lift cask

Spray cask with high-pressure water as removed from pool

Set cask down on decontamination pad

13. Prepare cask for shipment

Lift closure from the cask

Drain water from the cask to the pool, monitor while draining

Flush cask until release 1 imits are reached

Drain cask and remove drain line

Replace closure on cask, inspect each bolt, torque to specifications

Decontaminate the cask exterior to shipping release guidelines

14. Ship cask to the reactor

Move cask to rail car

Remove trunnions, install tie-downs and valve box covers

Reposition cooling ducts

Close and lock enclosures

Complete required check lists, surveys, bills of lading

Dispatch rail car to reactor

(a) G.E. 1973 . 


\subsubsection{Intermodal Transfer}

Intermodal transfer of casks can utilize either heavy lift equipment for transfer from one transport mode to another or the roll-on, roll-off technique. The type of transfer technique depends on the cask being used for shipment. For overweight truck (OWT) casks, either cranes or the roll-on, roll-off technique can be used. Rail casks are probably limited to heavy lifting equipment transfer because of the cask weight and the availability of rail equipment at docking facilities. In some cases, rail casks can use the rollon, roll-off technique for transfer from rail to barge where equipment is available.

A number of variations of the roll-on, roll-off technique have been developed to avoid the use of heavy cranes for cask handling. The simplest method of intermodal transfer for OWT casks makes use of heavy-duty rigging equipment including a set of heavy-weight dollies and a large mobile traction source. To unload from rail car to ship or barge, the rail car is jacked up and off its axles, set and tied down to dollies, moved onto the barge or ship and tied down.

Intermodal transfer between railroad and barge or ship may be done by using packaged rail cars that are not disassembled but are loaded directly onto the ship. The concept of a palletized rail cask and car can be used to advantage in intermodal transfer.

A complete rail car unit includes the cask, integral cask support expansion tanks, heat exchanger equipment, and a personnel barrier. The cars are 54 to $58 \mathrm{ft}$ long, $10 \mathrm{ft}$ wide and weigh 150 tons with a full NLI-10/24 cask.

\subsubsection{Cask and Disposition Facility Interface}

Cask handling operations at a fuel disposition facility would typically require a minimum of a 5- to 6-man operational crew consisting of: four operators including one crane operator, one health physics technician, and one operations supervisor. Typical unloading characteristics have been obtained for rail casks (Anderson 1978a). Figure 4.7 illustrates the generic operational flow path for a typical unloading sequence at a fuel receiving and storage station (taken from Anderson 1978a). 


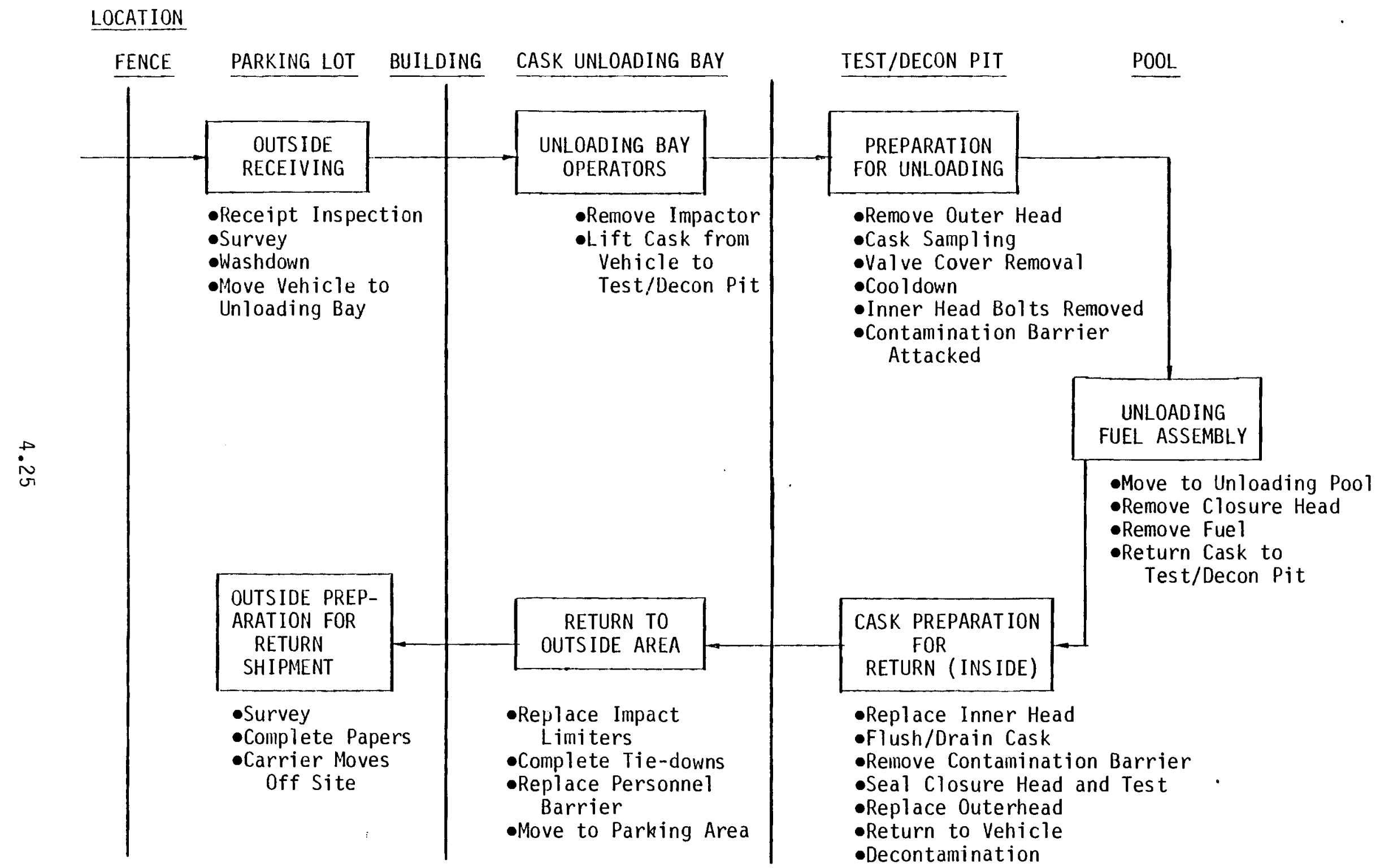

FIGURE 4.7. Unloading Operations Sequence at Fuel Disposition Facility (Anderson 1978a) 
.

.

.

. 


\subsection{FUEL SHIPMENT SCENARIOS}

In this study, scenarios for shipment of spent fuel are described on the basis of an intermodal transport sequence (ITS). The ITS is defined as a series of transportation and storage modes and transfer links connecting the origin and destination of the spent fuel. In this section, a generalized ITS is developed and equipment specifications for several basic scenarios are described in generic terms. Following this description is a discussion of the individual transport modes and of the various handling operations and transfer and auxiliary equipment involved in the ITS.

\subsection{BASIC SCENARIOS}

The basic scenarios considered in this study are listed in Table 5.1. For designation purposes, these scenarios correspond to the alternative modes of transport from the reactor to the federal interim storage (FIS) location. Figure 5.1 is a flow diagram of these scenarios showing the cask starting at a loading point where it is loaded onto a train or heavy-haul truck and shipped to the reactor via an intermodal transfer. For intermodal transfer from the reactor to the FIS, the shipment steps would be reversed from those shown in the figure. These scenarios include the combination of spent fuel casks and transportation methods ( $i . e$. , heavy-haul truck, train, and barge) that might be used in the future.

TABLE 5.1. Basic Intermodal Transport

Sequence Scenarios

\begin{tabular}{ll}
\multicolumn{1}{c}{ Cask Type } & $\frac{1}{\text { Transport Mode }}$ \\
\hline Rail & Heavy-Haul Truck to Rail \\
Rail & Barge to Rail \\
Rail & Barge to Heavy-Haul Truck \\
Transport/Storage & Heavy-Haul Truck to Rail \\
Transport/Storage & Barge to Rail \\
Transport/Storage & Barge to Heavy-Haul Truck
\end{tabular}




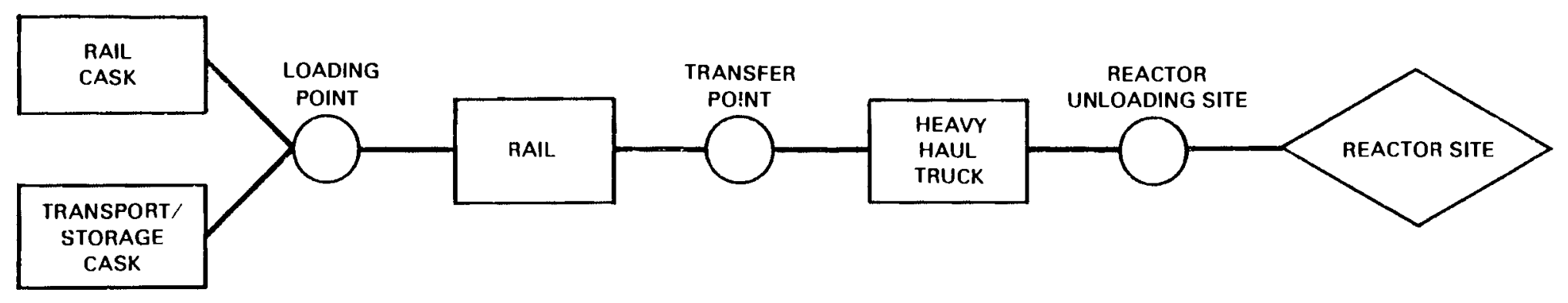

$\stackrel{\sim}{\sim}$
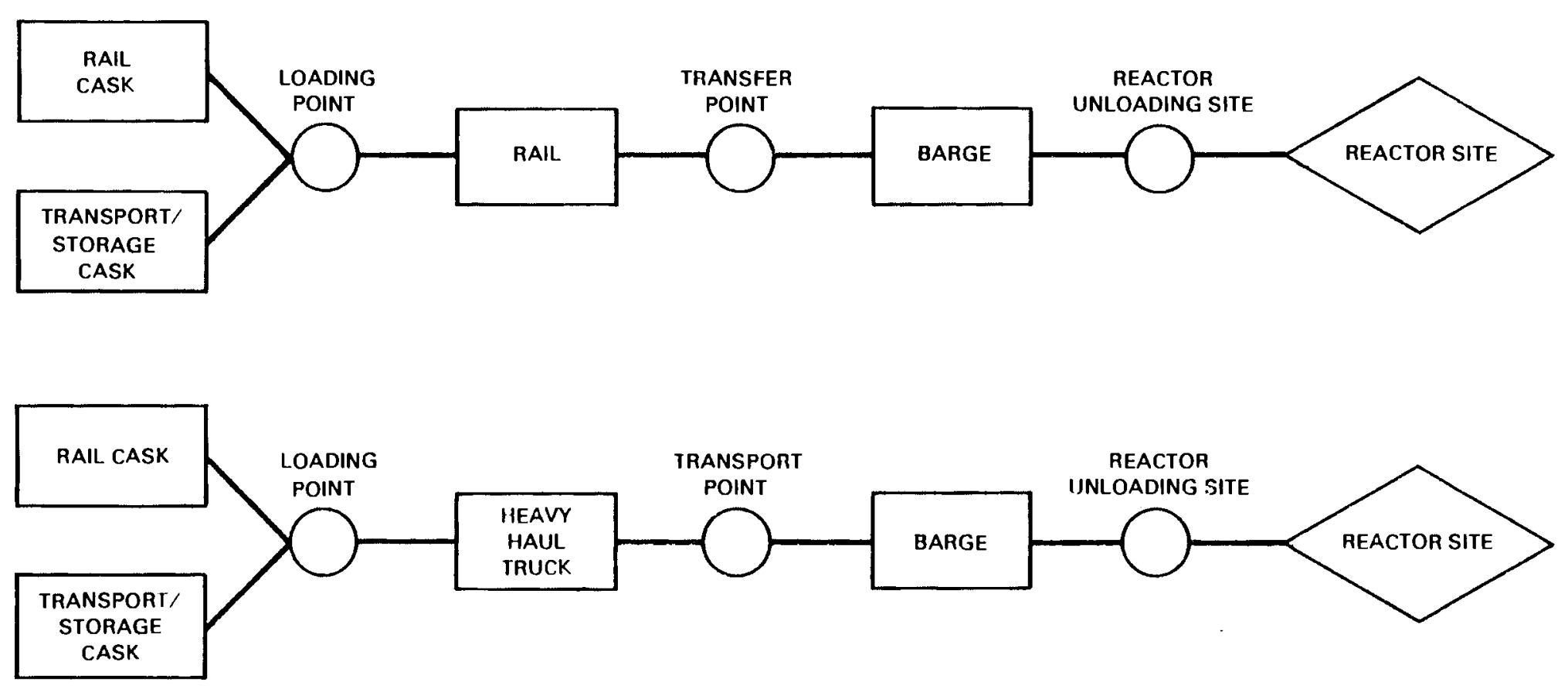

FIGURE 5.1. Basic Intermodal Transport Scenarios 


\subsection{INTERMODAL TRANSPORT SEQUENCE (ITS) DESCRIPTION}

A generalized ITS diagram is shown in Figure 5.2. Alternate modes of transport (e.g., truck, train, barge) and transfer (e.g., air pallet, truck dollies, or crane) can be used for different transportation links in the ITS. In the following discussion, the components of the ITS shown in Figure 5.2 are described in generic terms.

From storage at the FIS (Step 1), the spent fuel cask is picked up by air pallet or crane (Step 2) and moved with transfer equipment to a pad (Step 3) where a lifting device transfers the cask to the transport vehicle (Steps 4 and 5). Cranes are available at the storage location to load the cask onto the transport vehicle. From the cask storage location to the transfer point, the cask is assumed to be transported by heavy haul truck or train (Steps 6 and 7). The cask must then be transferred from the truck or train, to a storage pad at the transfer point (Steps 8 and 9 ).

At the transfer point the cask is transferred to the intermodal vehicle (rail, heavy haul truck or barge) by crane or roll-on, roll-off method (Step 10). It is then transported to the reactor site (Steps 12 and 13). At the reactor site, the cask is transferred (Step 14) to a DECON pad (Step 15) by a crane-lifting device or a roll-on, roll-off method. Cranes are available at the reactor site to handle spent fuel casks. The cask is cleaned, decontaminated and transferred by crane (Step 16) to the fuel pool. Spent fuel is then loaded in the cask at the fuel pool (Step 17). Once the fuel has been loaded, the cask is removed from the pool and transferred (Step 18) to the DECON pad (Step 19) where it is decontaminated and readied for shipment. The remainder of the ITS, sending the cask to disposition at the FIS facility, is done by reversing the order of the steps.

Tables 5.2, 5.3, and 5.4 describe in detail the ITS elements (corresponding to those of Figure 5.2) in each of the basic transport scenarios for rail and transport/storage casks.

Information provided in Tables 5.2 to 5.4 includes the ITS element, the intermodal activity (e.g., storage transfer or transport), the scope of work and any coinments, the equipment requirements for each ITS element, the estimated manpower requirements, and the number of persons required for each element. 


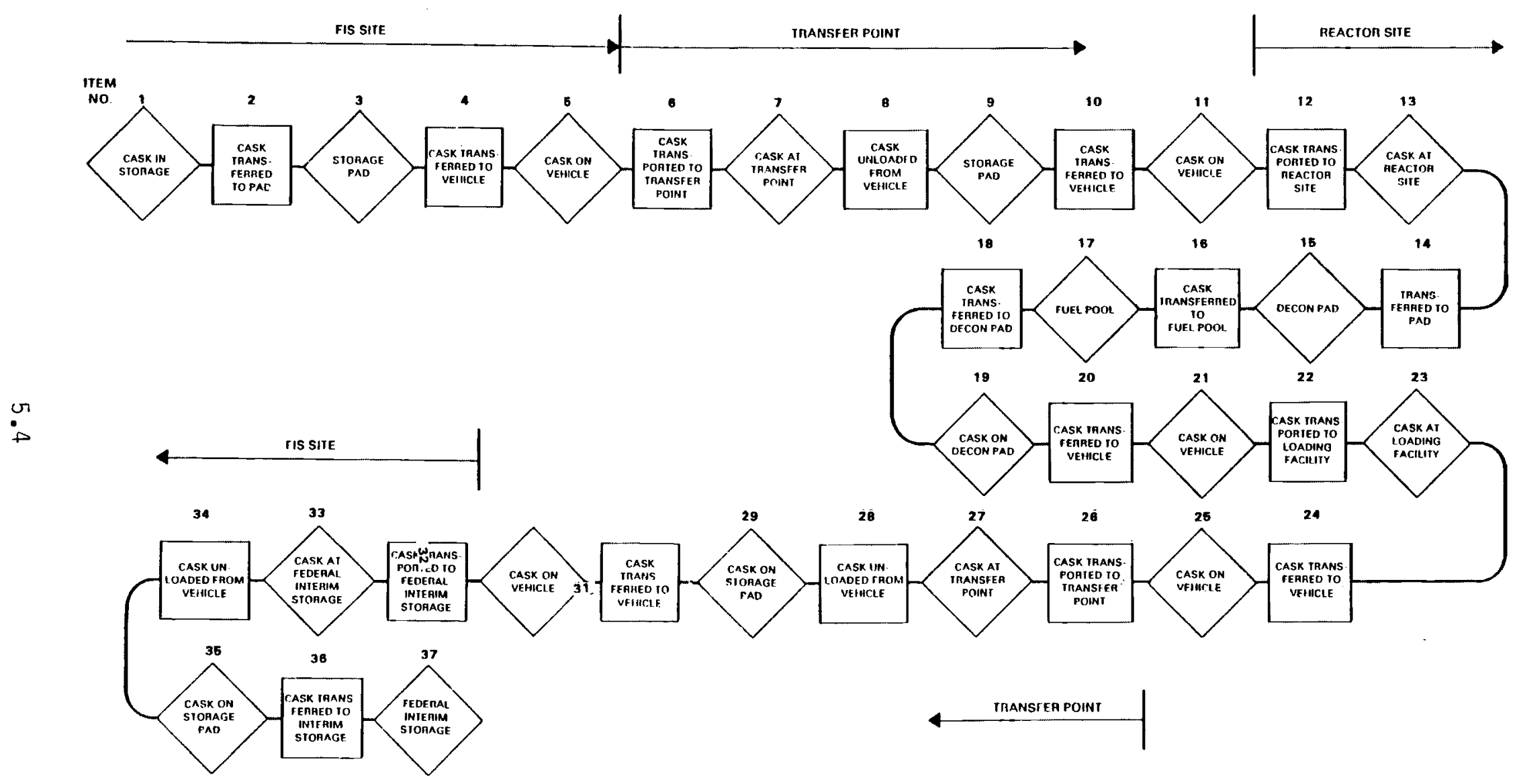

FIGURE 5.2. Generalized Intermodal Transport Sequence (ITS) 
TABLE 5.2. Intermodal Transport Sequence Data for Heavy-Haul Truck to Rail Baseline Scenario

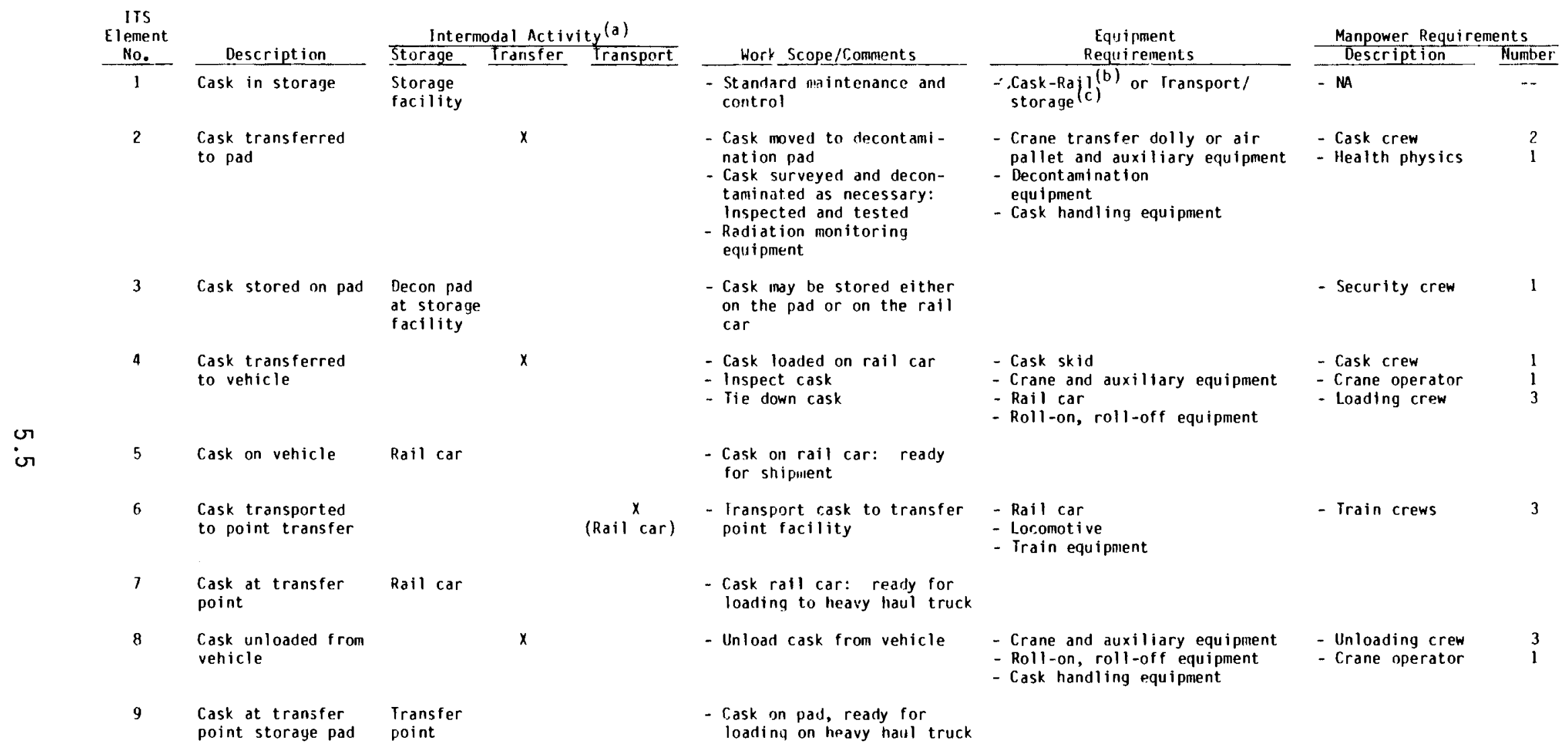


TABLE 5.2. (contd)

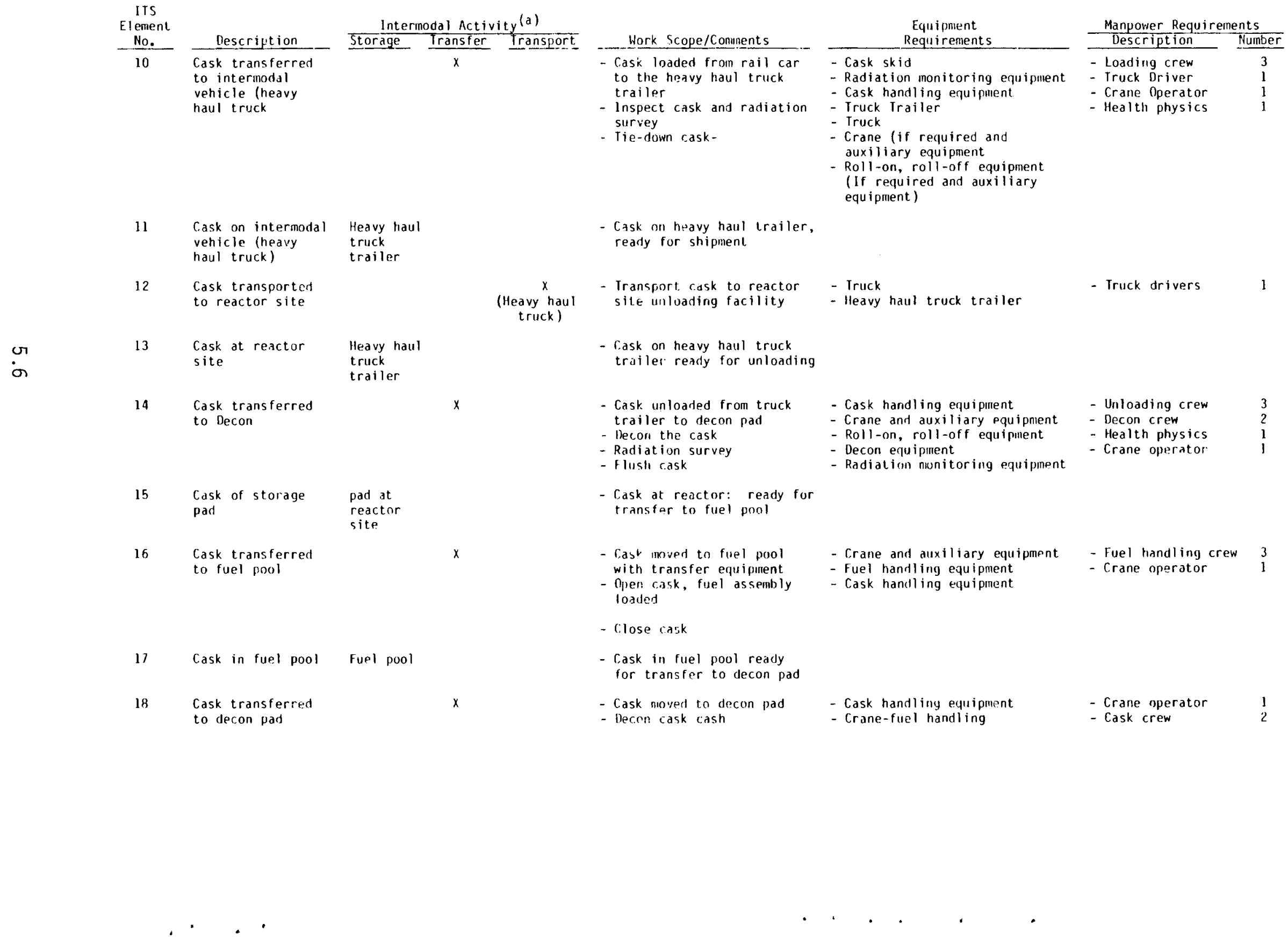


TABLE 5.2. (contd)

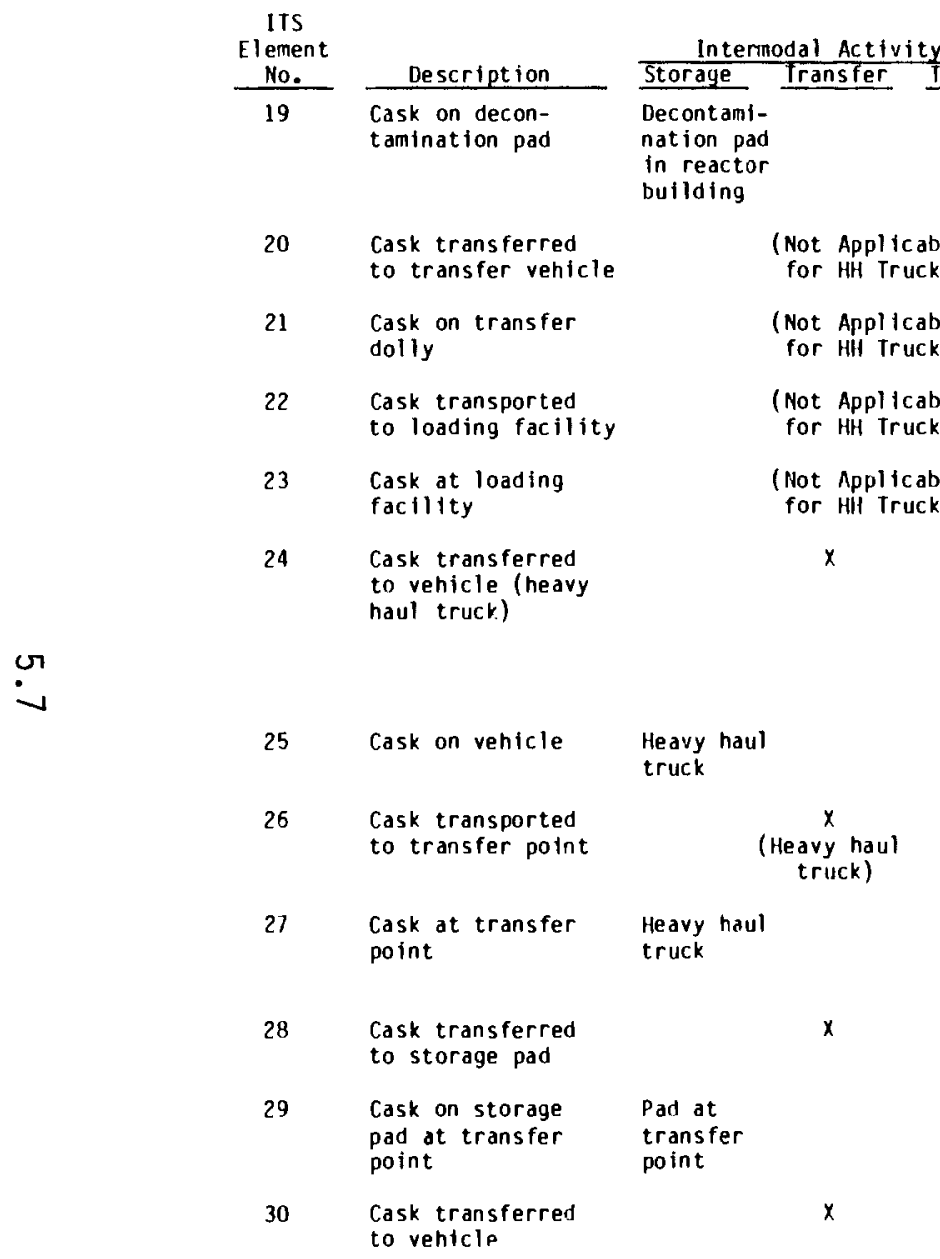

\section{\begin{tabular}{l} 
Work Scope/Comments \\
\hline - Cask stored on pad ready \\
for loading on heavy haul \\
truck
\end{tabular}}

Equipinent

$\frac{\text { Manpower Requirements }}{\text { Description }}$
- Cask loaded on heavy haul truck trailer

- Inspect cask

- Cask on heavy haul truck,

- Cask on heavy haul truck,

ready for shipment

- Transport cask and auxillary equitpment to transfer point

- Cask on heavy haul trafler at transfer port ready

- Unload cask from heavy

- Cask on pad: ready for loading on rail car

- Cask loaded on rail car
- Crane and auxiliary equipment - Roll-on, roll-off equipment

- Truck

- Heavy haul trailer

Cask skid

Truck equi pment

- Crane operator

- Truck driver

- Radiation

- Transfer crew

- Heavy haul trailer

Truck

- Truck driver

$\begin{array}{lll}\text { - Crane } & \text { - Unloading crew } & 3 \\ \text { - Roli-on, roll-off equipment } & \text { - Crane operator } & 1\end{array}$ - Crane operator
- Transfer crew
- Crane
- Roll-on, roll-off equi pulent
2

1
2
1
2

2


3
1

3


TABLE 5.2. (contd)

\begin{tabular}{|c|c|c|c|c|c|c|c|}
\hline \multirow{3}{*}{$\frac{\begin{array}{c}\text { Element } \\
\text { No. }\end{array}}{31}$} & \multirow[b]{2}{*}{ Description } & \multicolumn{2}{|c|}{ Intermodal Activity (a) } & \multirow[b]{2}{*}{ Work Scope/Comment 5} & \multirow{2}{*}{$\begin{array}{l}\text { Equi ipment } \\
\text { Requi rements }\end{array}$} & \multicolumn{2}{|c|}{ Manpower Requirements } \\
\hline & & Sturage Iransfer & Iransport & & & lescription & Number \\
\hline & Cask on vehicle & Rail car & & $\begin{array}{l}\text { - Cask loaded on rail car } \\
\text { ready for shipment }\end{array}$ & & & \\
\hline 32 & $\begin{array}{l}\text { Cask transported } \\
\text { to Federal interiun } \\
\text { storage facility }\end{array}$ & $\begin{array}{l}\text { Federal } \\
\text { interin } \\
\text { storage }\end{array}$ & (Rai) ${ }^{y}$ car) & $\begin{array}{l}\text { - Iransport cask to Federal } \\
\text { interim storage facility }\end{array}$ & $\begin{array}{l}\text { - Rail car } \\
\text { - Locomotive } \\
\text { - Irain equipment } \\
\text { - Auxiliary equipnent }\end{array}$ & - Irain crew & 4 \\
\hline 33 & $\begin{array}{l}\text { Cask at iTS } \\
\text { facility }\end{array}$ & rail car & & $\begin{array}{l}\text { - Cask at facility ready } \\
\text { for find disposition }\end{array}$ & & & \\
\hline 34 & $\begin{array}{l}\text { Cask transferred } \\
\text { to pad }\end{array}$ & $x$ & & - Cask mnved to storage pad & $\begin{array}{l}\text { - Crane } \\
\text { - Roll-on, roll-off equipment }\end{array}$ & $\begin{array}{l}\text { - Crane operator } \\
\text { - Unloading crew }\end{array}$ & $\begin{array}{l}1 \\
3\end{array}$ \\
\hline 35 & $\begin{array}{l}\text { Cask on storage } \\
\text { pad }\end{array}$ & $\begin{array}{l}\text { Pad at lTS } \\
\text { facility }\end{array}$ & & $\begin{array}{l}\text { - Cask on pad ready for } \\
\text { final disposition }\end{array}$ & & & \\
\hline 36 & $\begin{array}{l}\text { Cask transferred } \\
\text { to IIS }\end{array}$ & $x$ & & $\begin{array}{l}\text { - Cask inoved from pad to } \\
\text { fina! disposition } \\
\text { - Fuel unloaded }\end{array}$ & $\begin{array}{l}\text { - Crane or air pallet } \\
\text { - Cask handling equipment } \\
\text { - Truck Dollies }\end{array}$ & $\begin{array}{l}\text { - Crane operator } \\
\text { - Cask handling } \\
\text { crew }\end{array}$ & $\begin{array}{l}1 \\
3\end{array}$ \\
\hline 37 & $\begin{array}{l}\text { Cask at final } \\
\text { disposition }\end{array}$ & $\begin{array}{l}\text { Final dis- } \\
\text { position } \\
\text { facility }\end{array}$ & & & & & \\
\hline $\begin{array}{l}\text { (a) Ind } \\
\text { (b) Rail } \\
\text { (c) Irar }\end{array}$ & $\begin{array}{l}\text { cates type of activi } \\
\text { cask If-300 or NLI } \\
\text { sport storage cask }\end{array}$ & $\begin{array}{l}\text { for each ITS el ement } \\
/ 24 \text {. }\end{array}$ & storage, & ransfer, transport. & & & \\
\hline
\end{tabular}


TABLE 5.3. Intermodal Transport Sequence Data for Barge to Rail Baseline Scenario

\begin{tabular}{|c|c|c|c|c|c|c|c|c|}
\hline \multirow{3}{*}{$\begin{array}{c}\text { ITS } \\
\text { Element } \\
\text { No. }\end{array}$} & \multirow[b]{2}{*}{ Description } & \multicolumn{3}{|c|}{ Intermodal Activity (a) } & \multirow[b]{2}{*}{ Work Scope/Comments } & \multirow{2}{*}{$\begin{array}{c}\text { Equi inment } \\
\text { Requi rements }\end{array}$} & \multicolumn{2}{|c|}{ Manpower Requircments } \\
\hline & & Storage & Transfer & Iransport & & & Description & Nunber \\
\hline & Cask in storage & $\begin{array}{l}\text { Storage } \\
\text { facility }\end{array}$ & & & $\begin{array}{l}\text { - Standard raintenance and } \\
\text { control }\end{array}$ & 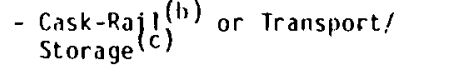 & - NA & - \\
\hline 2 & $\begin{array}{l}\text { Cask transferred } \\
\text { to pad }\end{array}$ & & $x$ & & $\begin{array}{l}\text { - Transfer cask to decon pad } \\
\text { - Cask surveyed and decon as } \\
\text { necessary: inspected and } \\
\text { tested }\end{array}$ & $\begin{array}{l}\text { - Crane transfer dolly or air } \\
\text { pallet } \\
\text { - Decon equipment } \\
\text { - Radiation monitoring equipment }\end{array}$ & $\begin{array}{l}\text { - Cask crew } \\
\text { - Health physics }\end{array}$ & $\begin{array}{l}2 \\
1\end{array}$ \\
\hline 3 & Cask stored on pad & $\begin{array}{l}\text { Decon pad } \\
\text { at storage } \\
\text { facility }\end{array}$ & & & $\begin{array}{l}\text { - NA - Cask may be stored } \\
\text { either on the pad or on } \\
\text { the rail car }\end{array}$ & & - Securfty crew & \\
\hline 4 & $\begin{array}{l}\text { Cask transferred } \\
\text { to vehicle }\end{array}$ & & $x$ & & - Iransfer cask to rail car & $\begin{array}{l}\text { - Crane } \\
\text { - Rail car }\end{array}$ & $\begin{array}{l}\text { - Cask crew } \\
\text { - Train crew }\end{array}$ & $\begin{array}{l}2 \\
3\end{array}$ \\
\hline 5 & Cask on vehicle & Rail car & & & $\begin{array}{l}\text { - Cask stored: really for } \\
\text { shipment }\end{array}$ & & & \\
\hline 6 & $\begin{array}{l}\text { Cask transported } \\
\text { to transfer point }\end{array}$ & & & (Rail ${ }^{x}$ car) & $\begin{array}{l}\text { - Transport cask to transfer } \\
\text { point farility }\end{array}$ & $\begin{array}{l}\text { - Locomotive } \\
\text { - Rail car }\end{array}$ & - Train crew & 3 \\
\hline 7 & $\begin{array}{l}\text { Cask at transfer } \\
\text { point }\end{array}$ & Rall car & & & $\begin{array}{l}\text { - Cask stured: ready for } \\
\text { loading }\end{array}$ & & & \\
\hline 8 & $\begin{array}{l}\text { Cask unloaded from } \\
\text { vehicle }\end{array}$ & & $x$ & & $\begin{array}{l}\text { - Unload cask from barge } \\
\text { deck }\end{array}$ & $\begin{array}{l}\text { - Cask skid } \\
\text { - Cask handling } \\
\text { - Crane or lift device }\end{array}$ & $\begin{array}{l}\text { - Unloading crew } \\
\text { - Crane operator }\end{array}$ & $\begin{array}{l}3 \\
1\end{array}$ \\
\hline 9 & $\begin{array}{l}\text { Cask at transfer } \\
\text { point storage } \\
\text { pad }\end{array}$ & $\begin{array}{l}\text { Transfer } \\
\text { point }\end{array}$ & & & $\begin{array}{l}\text { - Cask on storage pad, } \\
\text { ready for loading } \\
\text { on barge }\end{array}$ & & & \\
\hline 10 & $\begin{array}{l}\text { Cask loaded on } \\
\text { internodal vehicle } \\
\text { (barge) }\end{array}$ & & $x$ & & $\begin{array}{l}\text { - Iransfer cask from ratl } \\
\text { car to the barge } \\
\text { - Inspect cask and radia- } \\
\text { tion survey } \\
\text { - Tie-down cask }\end{array}$ & $\begin{array}{l}\text { - Cask skid (if required) } \\
\text { - Material handling system (MHS) } \\
\text { - Ship } \\
\text { - Crane (if required) } \\
\text { - Roll-on, roll-off equipment } \\
\text { - Radiation Monitoring Equipment }\end{array}$ & $\begin{array}{l}\text { - Loading crew } \\
\text { - Tughoat crew } \\
\text { - Health physics }\end{array}$ & $\begin{array}{l}3 \\
4 \\
1\end{array}$ \\
\hline 11 & Cask on vehicle & Barge & & & $\begin{array}{l}\text { - Cask on barge ready for } \\
\text { shipmient }\end{array}$ & & & \\
\hline 12 & $\begin{array}{l}\text { Cask transported } \\
\text { to reactor site }\end{array}$ & & & $\begin{array}{c}x \\
\text { (Barge) }\end{array}$ & $\begin{array}{l}\text { - Iransport cask to reactor } \\
\text { site unloading facility }\end{array}$ & $\begin{array}{l}\text { - Barge } \\
\text { - Tughoat equipment }\end{array}$ & - Tugboat crew & 4 \\
\hline
\end{tabular}


TABLE 5.3. (contd)

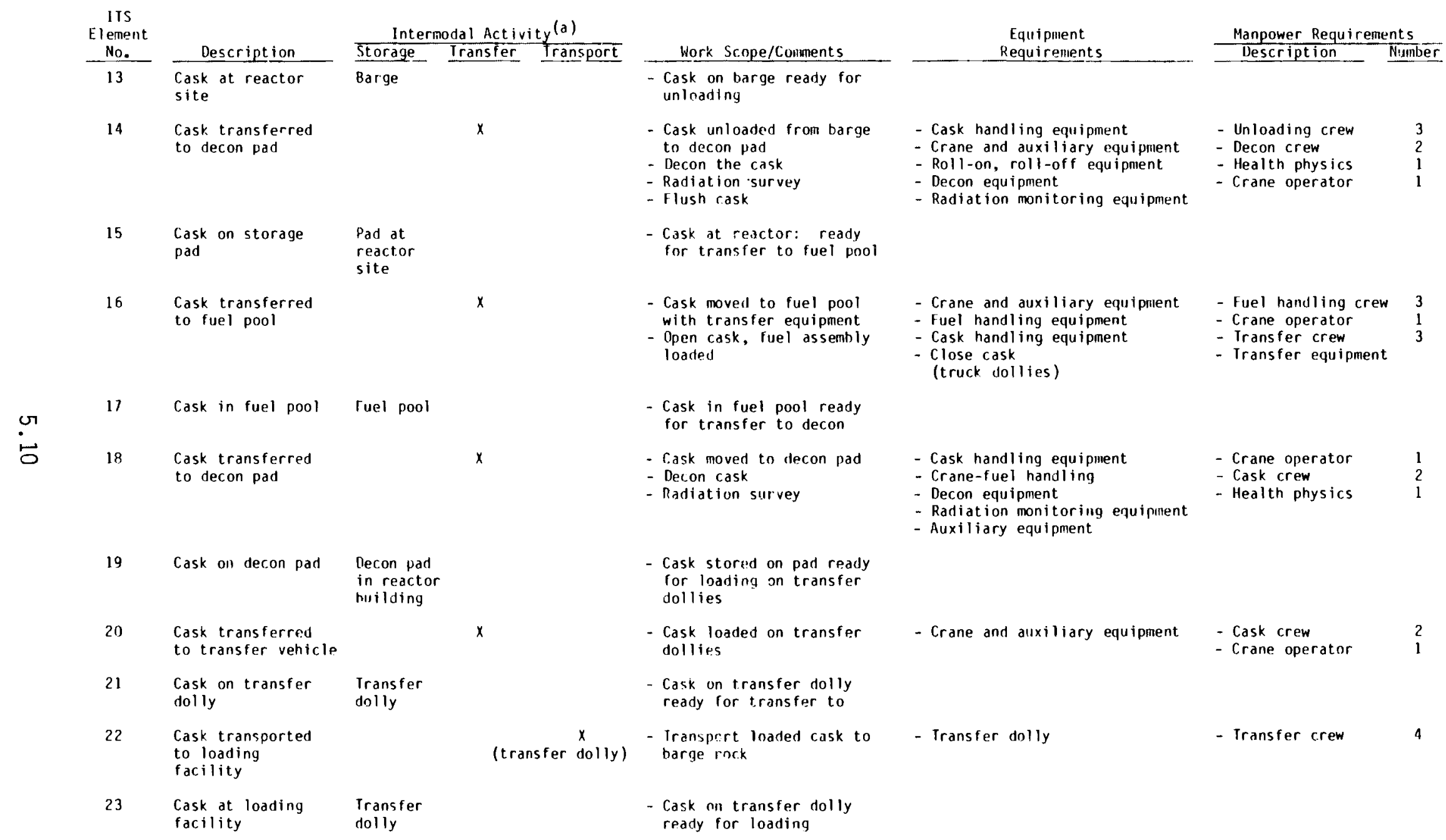


TABLE 5.3. (contd)

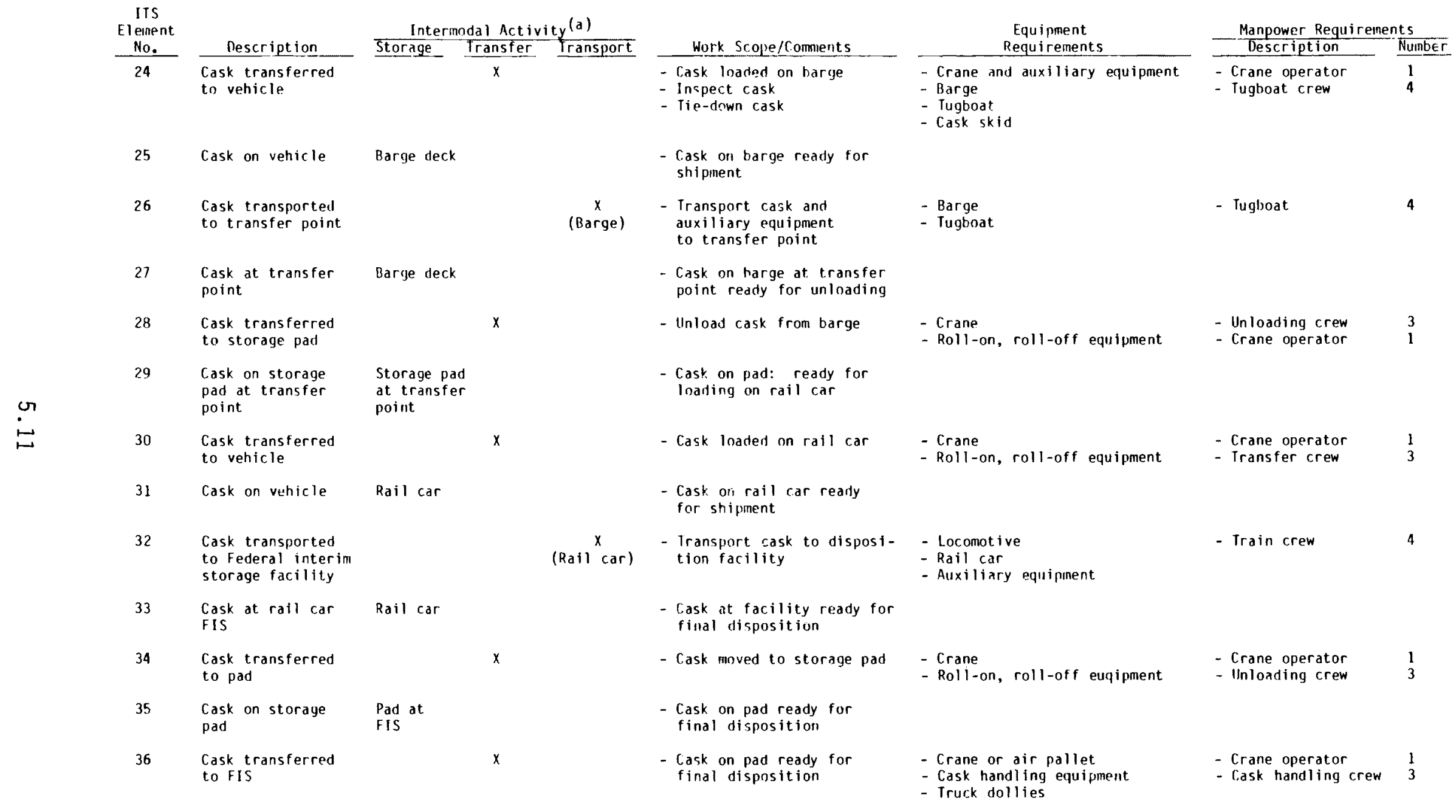


TABLE 5.3. (contd)

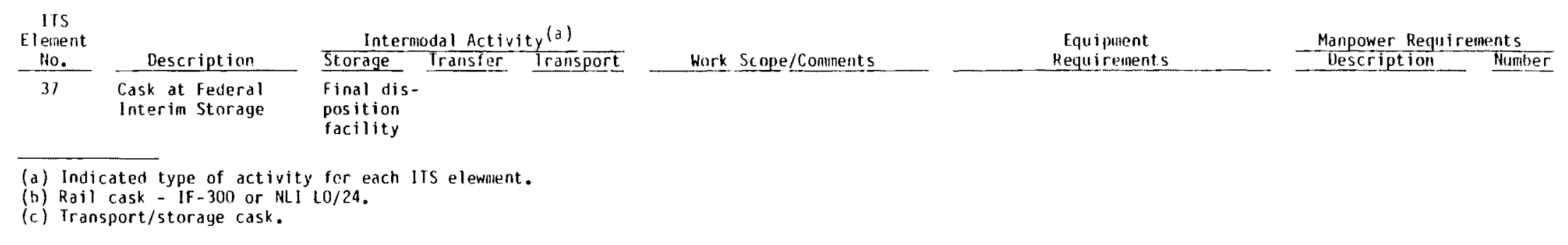


TABLE 5.4. Intermodal Transport Sequence Data for Barge to Heavy-Haul Truck Baseline Scenario

\begin{tabular}{|c|c|c|c|c|c|c|c|c|}
\hline \multirow{3}{*}{$\begin{array}{c}\text { IIS } \\
\text { El ement } \\
\text { No. }\end{array}$} & \multirow[b]{2}{*}{ Description } & \multicolumn{3}{|c|}{ Intermodal Activity(a) } & \multirow[b]{2}{*}{ Work Scope/Comments } & \multirow{2}{*}{$\begin{array}{c}\text { Equipment } \\
\text { Requirements }\end{array}$} & \multicolumn{2}{|c|}{ Manpower Requirements } \\
\hline & & Storage & Iransfer & Iransport & & & Description & Number \\
\hline & Cask in storage & $\begin{array}{l}\text { Storage } \\
\text { facility }\end{array}$ & & & $\begin{array}{l}\text { - Standard maintenance and } \\
\text { control }\end{array}$ & $\begin{array}{l}\text { - Cask-Ra } j_{(c)}^{(b)} \text { or transport./ } \\
\text { storage }\end{array}$ & $-M$ & - \\
\hline 2 & $\begin{array}{l}\text { Cask transferred } \\
\text { tn pad }\end{array}$ & & $x$ & & $\begin{array}{l}\text { - Iransfer cask to decon- } \\
\text { tamination pad } \\
\text { - Cask surveyed and decon- } \\
\text { taminated as necessary: } \\
\text { inspected and lested }\end{array}$ & $\begin{array}{l}\text { - Crane transfer dolly or air } \\
\text { pallet } \\
\text { - Decont amination equipment } \\
\text { - Survey equipment } \\
\text { - Radiation monitoring equipment }\end{array}$ & $\begin{array}{l}\text { - Cask crew } \\
\text { - Health physics }\end{array}$ & $\begin{array}{l}2 \\
1\end{array}$ \\
\hline 3 & Cask stored on pad & $\begin{array}{l}\text { Decon pad } \\
\text { at storage } \\
\text { facility }\end{array}$ & & & $\begin{array}{l}\text { - M - rask may be stored } \\
\text { either on the pad cr on the } \\
\text { heavy haul truck trailer }\end{array}$ & & & \\
\hline 4 & $\begin{array}{l}\text { Cask transferred } \\
\text { to vehicle }\end{array}$ & & $x$ & & $\begin{array}{l}\text { - Transfer cask to heavy } \\
\text { haul truck trailer }\end{array}$ & $\begin{array}{l}\text { - Heavy haul truck trailer } \\
\text { - Crane } \\
\text { - Roll-on, roll-off equipment }\end{array}$ & - Cask crew & 2 \\
\hline 5 & Cask on vehicle & $\begin{array}{l}\text { Heavy haul } \\
\text { truck } \\
\text { trailer }\end{array}$ & & & $\begin{array}{l}\text { - Cask stored: ready for } \\
\text { shipment }\end{array}$ & & & \\
\hline 6 & $\begin{array}{l}\text { Cask transported } \\
\text { to transfer point }\end{array}$ & & & $\begin{array}{c}x \\
\text { (Heavy haul } \\
\text { truck) }\end{array}$ & $\begin{array}{l}\text { - Transport cask to trans. } \\
\text { fer point facility }\end{array}$ & $\begin{array}{l}\text { - Heavy haul truck trailer } \\
\text { - Truck }\end{array}$ & - Truck drivers & 2 \\
\hline 7 & $\begin{array}{l}\text { Cask at transfer } \\
\text { point }\end{array}$ & $\begin{array}{l}\text { Heavy haul } \\
\text { truck } \\
\text { trailer }\end{array}$ & & & $\begin{array}{l}\text { - Cask stored: ready for } \\
\text { shipment }\end{array}$ & & & \\
\hline 8 & $\begin{array}{l}\text { Cask unloaded from } \\
\text { vehicle }\end{array}$ & & $x$ & & - Unload cask frum barge & $\begin{array}{l}\text { - Cask skid } \\
\text { - Crane or lift device } \\
\text { - Cask handling }\end{array}$ & - Unloading crew & 3 \\
\hline 9 & $\begin{array}{l}\text { Cask at transfer } \\
\text { point storage pad }\end{array}$ & $\begin{array}{l}\text { Transfer } \\
\text { point }\end{array}$ & & & $\begin{array}{l}\text { - Cask on storaye and ot } \\
\text { transfer point }\end{array}$ & & & \\
\hline 10 & $\begin{array}{l}\text { Cask lnaded on } \\
\text { intermodal vehicle } \\
\text { (barge) }\end{array}$ & & $x$ & & $\begin{array}{l}\text { - Transfer cask from heavy } \\
\text { haul truck trailer to } \\
\text { the barge } \\
\text { - Inspect cask and radia- } \\
\text { tion survey } \\
\text { - Tie-down cask }\end{array}$ & $\begin{array}{l}\text { - Cask skid (if required) } \\
\text { - Material handling system } \\
\text { (Mis) - tugboat } \\
\text { - Barge } \\
\text { - lugboat } \\
\text { - Crane (if required } \\
\text { - Roll-on, roll-off equipment }\end{array}$ & $\begin{array}{l}\text { - Loading crew } \\
\text { - Tugboat crew } \\
\text { - Health physics }\end{array}$ & $\begin{array}{l}3 \\
4 \\
1\end{array}$ \\
\hline
\end{tabular}


TABLE 5.4. (contd)

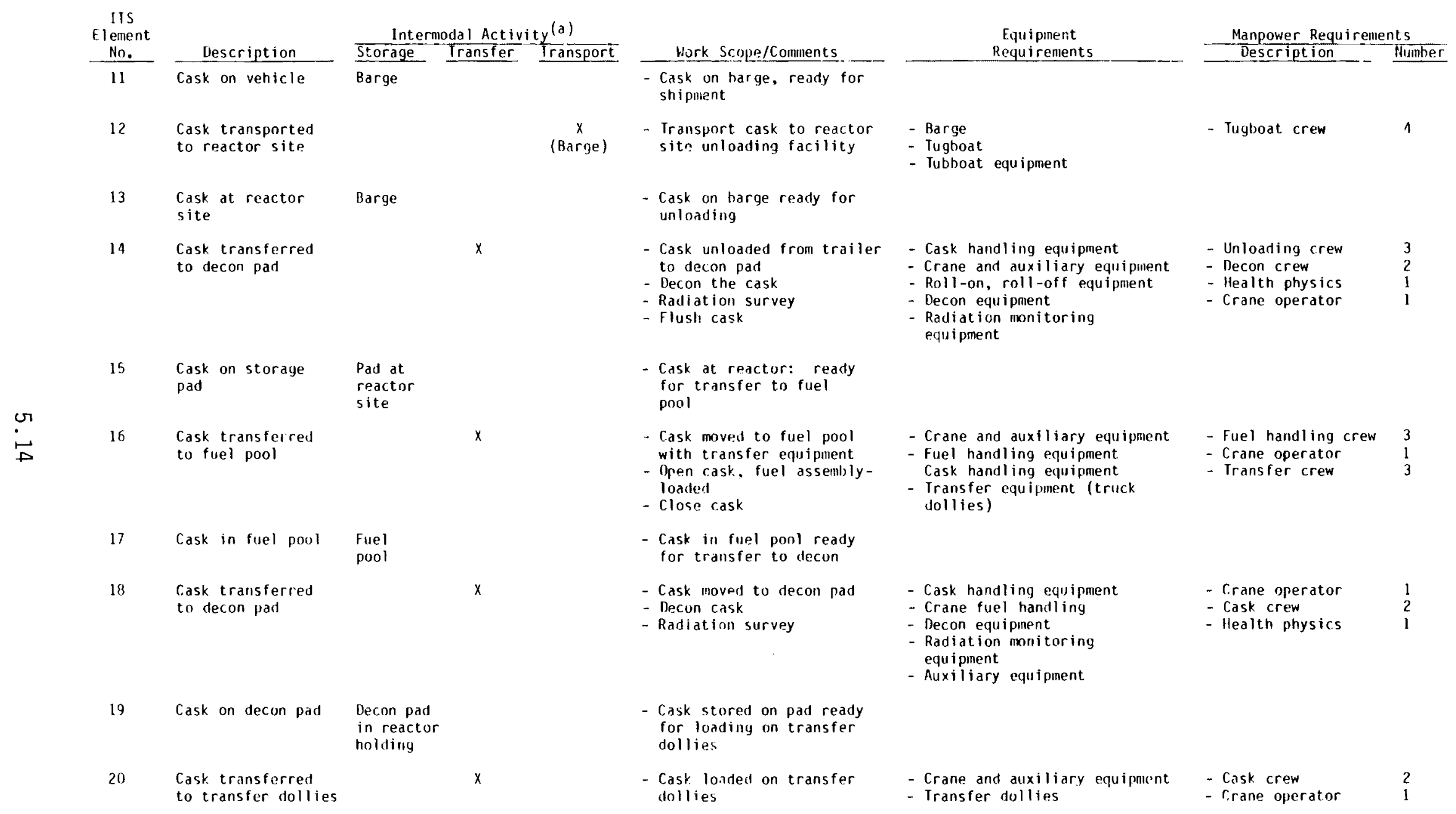


TABLE 5.4. (contd)

\begin{tabular}{|c|c|c|c|c|c|c|c|c|}
\hline $\begin{array}{c}\text { ITS } \\
\text { El emient }\end{array}$ & & Interm & odal Act iv & vity (a) & & Equi ipment & Manpower Requi & \\
\hline No. & Description & Storage & Transfer & Transport & Work Scope/Cominents & Requi reinents & Description & Number \\
\hline 21 & $\begin{array}{l}\text { Cask on transfer } \\
\text { dolly }\end{array}$ & $\begin{array}{l}\text { Iransfer } \\
\text { dolly }\end{array}$ & & & $\begin{array}{l}\text { - Cask on transfer dolly } \\
\text { ready for shipment to } \\
\text { barge dock }\end{array}$ & & & \\
\hline 22 & $\begin{array}{l}\text { Cask transported } \\
\text { to barge dock }\end{array}$ & & & $\begin{array}{c}x \\
\text { (Transfer } \\
\text { dolly) }\end{array}$ & $\begin{array}{l}\text { - Transport loaded cask to } \\
\text { barge dock }\end{array}$ & - Transfer dolly & - Iransfer crew & 4 \\
\hline 23 & Cask at barge dock & $\begin{array}{l}\text { Transfer } \\
\text { dolly }\end{array}$ & & & $\begin{array}{l}\text { - Cask on transfer dolly, } \\
\text { ready for loading }\end{array}$ & & & \\
\hline 24 & $\begin{array}{l}\text { Cask transferred } \\
\text { to vehicle (barge) }\end{array}$ & & $x$ & & $\begin{array}{l}\text { - Cask loaded on barge } \\
\text { - Inspect cask } \\
\text { - Tie--down cask }\end{array}$ & $\begin{array}{l}\text { - Crane and auxiliary equipment } \\
\text { - Roll-on, roll-off equipment } \\
\text { - Barge } \\
\text { - Tugboat } \\
\text { - Cask skid }\end{array}$ & $\begin{array}{l}\text { - Crane operator } \\
\text { - Tugboat crew }\end{array}$ & $\begin{array}{l}1 \\
4\end{array}$ \\
\hline 25 & Cask on vehicle & Barge & & & $\begin{array}{l}\text { - Cask on barge ready for } \\
\text { shipment. }\end{array}$ & & & \\
\hline 它 & $\begin{array}{l}\text { Cask transported } \\
\text { to transfer point }\end{array}$ & & & $\begin{array}{c}x \\
\text { (Barge) }\end{array}$ & $\begin{array}{l}\text { - Transport cask and } \\
\text { auxiliary equipment to } \\
\text { transfer point }\end{array}$ & $\begin{array}{l}\text { - Barge } \\
\text { - Tugboat }\end{array}$ & - Tugboat crew & 4 \\
\hline 27 & $\begin{array}{l}\text { Cask at trans- } \\
\text { fer point }\end{array}$ & Barge dock & & & $\begin{array}{l}\text { - Cask on harge at transfer } \\
\text { point ready for unloading }\end{array}$ & & & \\
\hline 28 & $\begin{array}{l}\text { Cask transferred } \\
\text { to storage pad }\end{array}$ & & $x$ & & - Unload cask from barge & $\begin{array}{l}\text { - Crane } \\
\text { - Roll-on, roll-off equipment }\end{array}$ & $\begin{array}{l}\text { - Unloading crew } \\
\text { - Crane operator }\end{array}$ & $\begin{array}{l}3 \\
1\end{array}$ \\
\hline 29 & $\begin{array}{l}\text { Cask on storage } \\
\text { pad at transfer } \\
\text { point }\end{array}$ & $\begin{array}{l}\text { Storage } \\
\text { transfer } \\
\text { point }\end{array}$ & & & $\begin{array}{l}\text { - Cask on pad: ready for } \\
\text { loading on heavy haul } \\
\text { truck }\end{array}$ & & & \\
\hline 30 & $\begin{array}{l}\text { Cask transferred } \\
\text { to vehicle }\end{array}$ & & $x$ & & $\begin{array}{l}\text { - Cask loaded on heavy haul } \\
\text { truck trailer }\end{array}$ & $\begin{array}{l}\text { - Crane } \\
\text { - Roll-on, roll-off equipinent }\end{array}$ & $\begin{array}{l}\text { - Crane operator } \\
\text { - Transfer crew }\end{array}$ & 1 \\
\hline 31 & Cask on vehicle & $\begin{array}{l}\text { Heavy haul } \\
\text { truck } \\
\text { trailer }\end{array}$ & & & $\begin{array}{l}\text { - Cask on heavy haul trailer } \\
\text { ready for shipment }\end{array}$ & & & \\
\hline 32 & $\begin{array}{l}\text { Cask transported } \\
\text { to Federal Interim } \\
\text { Storage facility }\end{array}$ & & & $\begin{array}{c}x \\
\text { (Heavy haul } \\
\text { truck) }\end{array}$ & $\begin{array}{l}\text { - Iransport cask to Federal } \\
\text { Interim Storage facility }\end{array}$ & $\begin{array}{l}\text { - Truck } \\
\text { - Heavy haıl truck trailer } \\
\text { - Auxiliary equipment }\end{array}$ & - Truck drivers & 2 \\
\hline
\end{tabular}


TABLE 5.4. (contd)

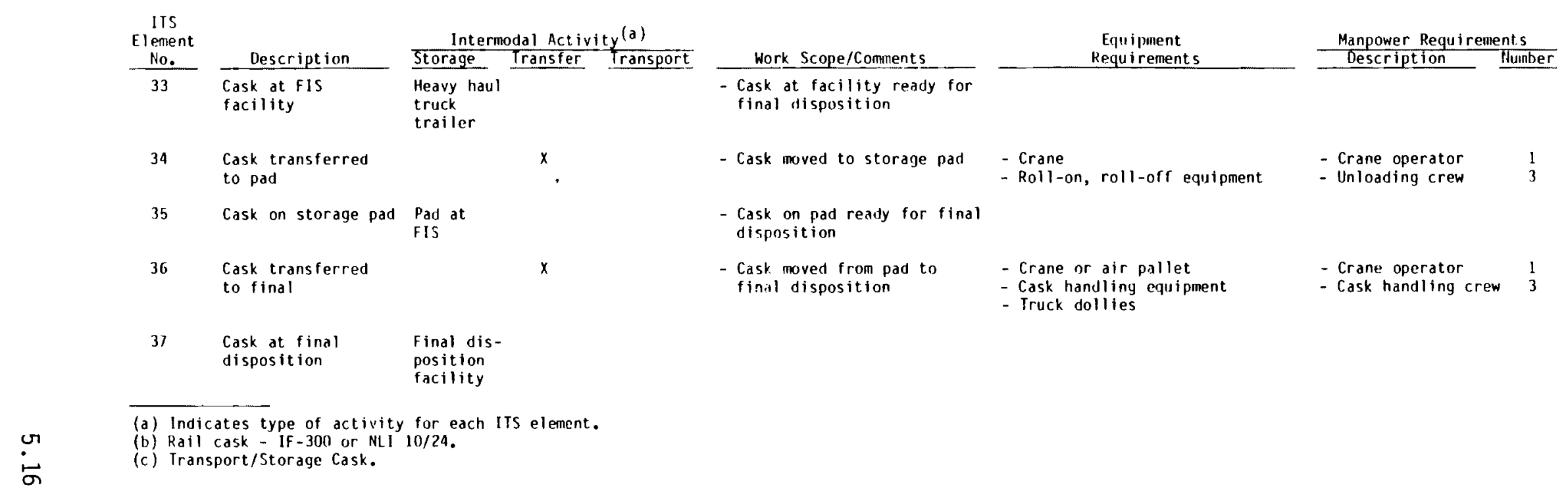


The tables denote the intermodal activity for each of the ITS elements whether the spent fuel is in storage, transfer, or transport. The work scope at each ITS element is listed in the tables along with the equipment and manpower requirements for that activity.

The information developed in these tables is used in Section 6 to evaluate the availability and requirements of intermodal transport and to determine whether intermodal transport can be accomplished.

\subsection{SHIPMENT SCENARIOS}

Transportation scenarios involving intermodal alternatives between the cask loading location, the reactor site, and the FIS are described in this section. Transportation facilities and equipment needed for each mode are listed. 5.3.1 Rail Transport

Rail transport requires the use of existing railheads. If there is no railhead at the reactor site, a heavy-haul highway transporter is required for the portion of the route connecting with the reactor plant. In this case, the rail car and cask to be unloaded are secured in place against an unloading ramp. An auxiliary trailer is used as a temporary ramp in conjunction with the permanent ramp. A jeep dolly, goosenecks, and rear assembly are attached to the cask skid, which thus becomes a trailer suitable for highway use (see Figure 4.4). A tractor provides the motive power. The highway transporter is driven off the rail car, down the ramp and is ready to proceed to the reactor site. As an alternative, a straddle crane can be used for cask/skid unloading at the railhead.

A complete investigation of the route must be made to minimize problems on the selected route. There should be adequate vertical clearance between the unit and the road surface, minimal sharp horizontal curves and no steep grades. Overhead clearances, bridges and spans, culverts and underground structures and the load-bearing characteristics of the road itself must be thoroughly investigated and necessary corrective actions taken before passage of the highway transporter. Assuming that the route is satisfactory, the cask on the highway transporter is hauled to the reactor site, unloaded, moved into the reactor building, and placed in the fuel pool. 
Following fuel loading and placement of the cask and equipment skid outside the access dock, the tractor and rear dolly may need to be reversed so that the equipment skid is in the same configuration on the flatcar as upon arrival at the railhead.

The highway transporter and loaded cask are driven back to the railhead ramp site and the loaded cask and equipment skid are loaded on the railroad flatcar.

Equipment required in using the rail car method of transport is listed below:

- irradiated fuel casks

- railroad flatcars

- equipment skids to support cask during land and water transportation

- cask-lifting device (spreader bars, cables, etc.) to travel with casks

- specialized heavy hauling highway transporter (if railhead is not at reactor site)

- truck tractor

- tanden trunnion jeep dolly

- nydraulic-removable gooseneck

- hydraulic-removable rear-axle assembly

- trailer, auxiliary

- ramp and bridge sections, other auxiliary equipment

- spare equipment and parts

- ramp site, paved, flat or with moderate slope at nearest railhead accessible to the reactor site, fenced, with equipment storage area

- loading/unloading ramp and highway transporter naneuvering area at rainp site

- railroad siding, constructed or modified at ramp site to include trackage, switching, and storage capacity for railroad cars. 


\subsubsection{Barge Transport}

Over 100 existing or proposed domestic nuclear plants are on a navigable waterway, although not all of these plants are prime candidates for water transportation (AIF 1978). A large number of these are served by rail. Some plants are located sufficiently far from actual and proposed receipt facilities that barge transport is clearly impractical. However, there are a number of sites where barges may present the best alternative shipping mode. Table 5.5 is a list of power sites on navigable waterways where there is more than one reactor, and no railroad access. All of the reactor plants listed in Table 1.1 that require movement of spent fuel by 1989 and do not have rail access are located on navigable waterways.

IABLE 5.5. Reactor Sites on Navigable Waterways (a)

\section{Facility Name}

Rrowns Ferry 1, 2, 3

Calvert Cliffs 1,2

St. Lucie 1, 2

Indian Point 1, 2, 3

Point Beach 1, 2

Salem N.G.S. 1, 2

Pilgrim N.P.S. 1, 2

Surry P.S. 1,2

Turkey Point 3,4

\begin{tabular}{l} 
Location \\
\hline Limestone, Alabama \\
Calvert, Maryland \\
Ft. Pierce, Florida \\
Buchanan, New York \\
South of Green Bay, Wi sconsin \\
Salem, New Jersey \\
Plymouth, Massachusetts \\
Surry, Virginia \\
Dade, Florida
\end{tabular}

Navigable haterway

Wheeler Lake/Tennessee River

Chesapeake Bay

Indian River

Hudson River

Lake Michigan

Del aware Bay

Cape Cod Bay

James River

Biscayne Bay

(a) Source: Anderson and Jones 1980.

Those plants without rail access and having water transport capability are candidates for barge transport. An evaluation of the feasibility of water shipinent would include the following areas:

Capacity - Several rail casks could be carried on a barge or small ship. Safety - the role of the intermodal shipping mode must be reviewed for safety. General indications are that it is a safe mode of shipment. On a comparative basis, barge shipment is as safe as highway or rail (Anderson and Jones 1980). 
Physical Security - Barge shipments have certain security advantages:

- barge shipments follow defined routes

- barge shipment routes bypass urban areas

- diversion attempts are mitigated by heavy weight of the casks

- the operationing crew and communication equipment are already in place.

Equipment Considerations for Water Transport - No matter what shipping cask is used, there are three specific equipment areas that must be examined for intermodal or water-only transport:

1. Shipping Package/Transport Vehicle Integration. llost shipping casks are designed to be combined with dedicated vehicles (trailers, rail cars). In certain cases, the package has a shipping skid that can be removed from the vehicle. This concept is used for the GE IF-300 skid illustrated in Figure 4.4. The shipping skid must contain all of the auxiliary equipment required for the shipping package en route. Another option, wherein the shipping package and vehicle remain together, is frequently denoted as roll-on/roll-off (RO/RO) (see Figures 5.3 and 5.4). In this circunstance, it may be necessary to replace the rail car iron wheels (Figure 5.3) with rubber wheels (Figure 5.4) to perinit the movement. In either case, of either integrated or separated package/vehicle shipments, there is a need for special equipment at the site where the intermodal transfer is made.

2. Small Ship or Barge Shipment. The use of either a small ship or various barge configurations is predicated on the degree of control required for the package. The possible means are listed from high degree of control to low degree: (a) motor vessel, (b) rigid link barge, (c) notched barge, (d) standard "push" barge, and (e) stern tow. Towing a barge from the stern, at least where spent fuel is being shipped, appears to be unacceptable. 


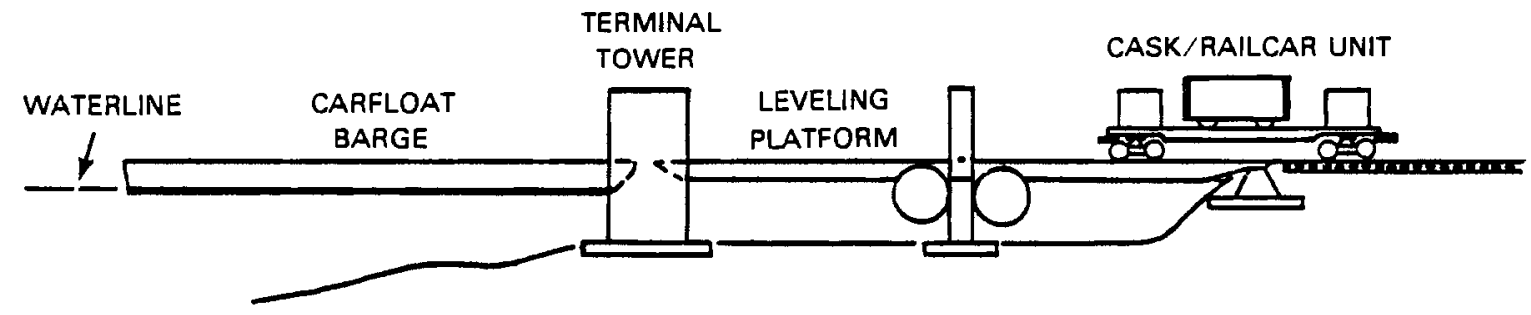

FIGURE 5.3. Floating Bridge Roll-0n/Roll-off Transferral Process(a)

(a) Source: Anderson and Jones 1980.

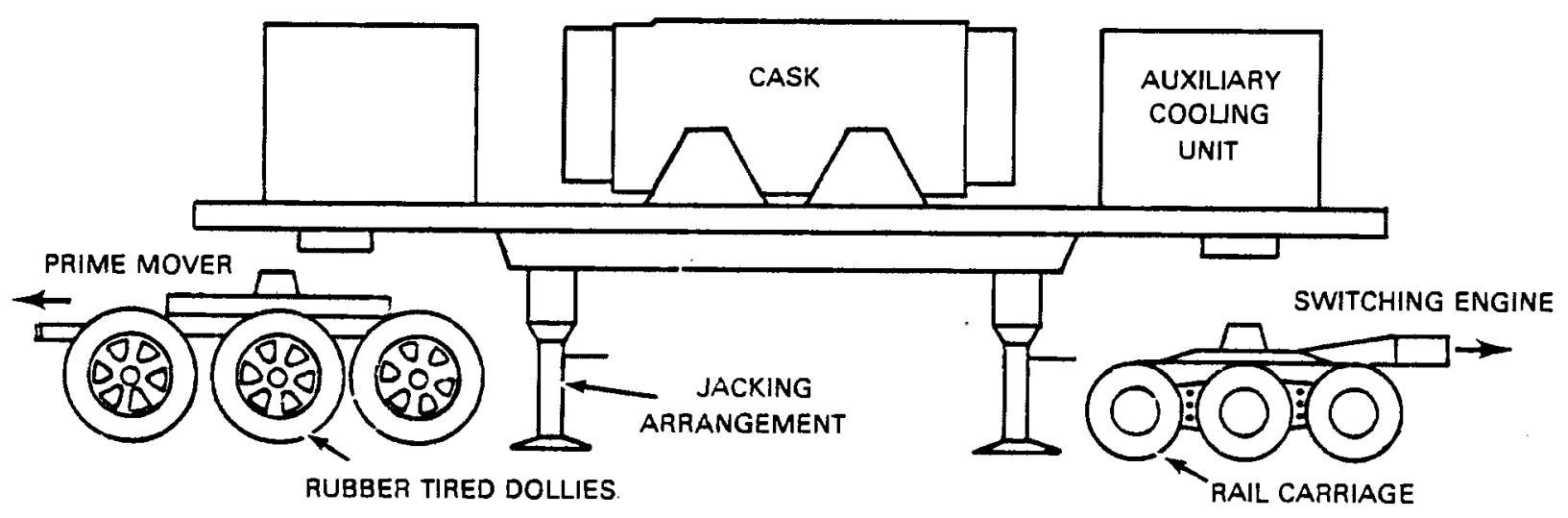

FIGURE 5.4. HHT Roll-On/Roll-0ff Transferral Process(a)

(a) Source: Anderson and Jones 1980.

Control of the barge en route is primarily a safety concern. Towboat control of the barge when there is a rigid link is obviously greater than when a hawser is employed. In the latter case, there is a greater possibility of collision. With a rigid link, the barge can be frequently boarded for inspection purposes.

A study by AGNS of domestic water shipments compared a notched barge and a shallow draft motor vessel. The comparisons are given in Table 5.6 (Anderson and Jones 1980). The increased cost of the motor 


\section{TABLE 5.6. Advantages/Disadvantages of Barge Versus Separate Motor Vessel for Transport of Radioactive Material Packages}

I. BARGE (notched)

Advantages:

1. Shallow draft and thus greater flexibility of use at reactor sites without necessity of special dredging operations.

2. Lower capital investment, lower operating costs, and smaller crew resulting in lower transportation cost.

3. The conventional nature of the tow-boat would allow its use in other services when not fully utilized in this dedicated service.

4. An expanded system of additional barges and tow-boats would provide the utmost in flexibility of operation.

Disadvantages:

1. Higher insurance costs and susceptibility to weather delays.

2. Integrity and maneuverability are less favorable than for self-propelled motor vessels.

3. Recent accidents or near accidents involving barge use have caused greater USCG scrutiny of all barge movements. Consequently, greater difficulty in obtaining USCG approvals is expected as compared to the self-propelled motor vessel.

II. MOTOR VESSEL

Advantages:

1. The self-propelled vessel provides greater integrity and maneuverability.

2. Lower insurance rates are available.

3. Motor vessel has greater ability to continue normal operations in rough weather.

Disadvantages:

1. Greater draft may require some dredging near certain reactor sites.

2. The following contribute to its less favorable economics and increased financial risk:

(a) Larger crew size.

(b) Higher costs of operation and cost of landing facility.

(c) With one motor vessel, operations stop if mechanical difficulties occur.

(d) No other use can be counted on for the specialized vessel when not utilized in this dedicated service (charter required).

3. Any additions to the fleet would require additional long-term commitment and accompanying greater risk if the equipment is not fully utilized. 
vessel would probably limit its consideration at this time, unless handling a large number of casks were envisioned.

3. Shipping Logistics. Tradeoffs related to the number of casks in a barge shipment and the distance to be moved must be considered. The lease cost of large spent fuel casks is several thousand dollars per day. The time required to load and unload these casks can be several days. Since crews and equipment must be available at several locations, the logistic optimization must be considered unique for each application. 


\subsection{EVALUATION OF SYSTEMS AND EQUIPMENT}

This section evaluates the intermodal transportation scenarios discussed in Section 5, the various transport systems used to transport the casks, and the handling systems involved in cask movements. This information is used to assess the availability of equipment and transport methods and to determine whether intermodal transport of spent fuel in the United States is feasible.

\subsection{SPENT FUEL SHIPMENT SCENARIOS}

A discussion of the variables that can influence the schedule of fuel shipments, the transport time, and the equipment and manpower availability is presented in this section for each of the spent fuel shipment scenarios.

To make a comparison of the different cask intermodal transport systems on the basis of transit time, it was assumed that one-third of a PWR reactor core, consisting of about 72 spent fuel assemblies, would be transported to federal interim storage. For the rail cask, it was assumed each shipment would move 2 casks, carrying 7 assemblies each.

Only the steps for the heavy-haul truck to rail scenario are outlined in detail in this section. The steps for the barge to rail and the barge to heavyhaul truck scenarios are summarized because they are similar to those for the heavy-haul truck to rail scenario. These steps correspond to those listed in Tables $5.2,5.3$, and 5.4 in Section 5 .

\subsubsection{Heavy-Haul Truck to Rail Transport Scenario}

A typical fuel shipment scenario, including a discussion of variables that could influence the schedule of fuel shipments, is presented in this section. The assumptions used for this scenario are:

- 2 casks are used

- cask is IF-300 on equipment skids

- cask capacity is 7 PWR fuel assemblies

- refueling cycle is 18 months

- 72 per unit, 2 units $=144$ fuel assemblies per year.

The steps described in this scenario are defined in Section 5, Figure 5.2 . 


\subsubsection{Details of Spent Fuel Shipment Scenario}

Step (1) Cask in Storage (empty casks)

- The storage facility is the principal point for cask maintenance, logistics, engineering, and spare parts.

- Loading Time

1.5 days

Steps (1) to (9) Cask in Storage to Cask at Transfer Point (empty casks)

- The empty cask is transported via train from the storage facility to the transfer point. Assume $4 \mathrm{mph}$ average train speed and storage location 500 miles from reactor location.

- Transit time

Step (10) Cask Transferred to Heavy-Haul Vehicle (empty casks)

- The empty cask and skid will be transferred to the heavy-haul truck. A heavy-haul trailer similar to the IF-300 is required to other casks.

- With the rail unloading facility not at the reactor site, an intermodal, heavy-haul rig is needed for the move to and from the reactor site. The rig consists of hydraulic gooseneck-wheeled assemblies capable of lifting a cask skid from the ground, plus a tractor.

- For transferring the cask and skid to the heavy-haul rig, a roll-on/rolloff facility is required. A 100-ton straddle crane is an alternative system.

- Switching and storage tracks must be available at the transfer point.

- Loading and securing time

$\underline{1.5 \text { days }}$

Steps (11) to (12) Cask Transported to Reactor Site (empty casks)

- Casks require no maintenance or monitoring.

- Casks will be shuffled to the reactor site singly. After the first empty unit the rig returns to the railhead and picks up the second empty unit. The process continues until all loaded casks are back at the railhead.

- Each intermodal movement may require escorts for traffic control due to the size and slow speed of the rig. 
- Movements may be required only during daylight hours at low traffic periods.

- Transit time for the heavy-haul vehicle to the reactor site (assume $8 \mathrm{miles}$ )

$\underline{1 \text { day }}$

Step (13) Cask at Reactor Site (empty casks)

- Area must be secure with illumination for night work. Air, electricity, and equipment storage are required.

- Unloading time

$\underline{1.5 \text { days }}$

Steps (14) to (17) Cask at Site to Fuel Pool (empty/loaded casks)

- A cask/skid transfer and storage pad will be necessary. This facility is required for temporary cask placement while another unit is being moved into or out of the reactor building.

- The cask skid will be reconfigured and a prime mover used to move the cask and skid into the reactor building. The intermodal transport rig is too large to accomplish this task.

Step (17) Cask at Fuel Pool (cask loaded)

- Turnaround time within the reactor building is assumed to be 2 days, per cask

4 days

Steps (17) to (25) Cask in Fuel Pool to Cask on Vehicle (loaded cask on heavyhaul truck)

- Return to transfer point and load on rail car 2.5 days

Steps (25) to (27) Cask on Vehicle to Cask at Transfer Point (loaded cask)

- Transit time

1 day

Step (27) Cask at Transfer Point (loaded cask)

- Unloading from heavy-haul truck and putting on rail cars

$\underline{2 \text { days }}$

Steps (27) to (37) Cask at Transfer Point to FIS site (loaded cask)

- Transport via train to disposition facility under

10 CFR 73 requirements for in-transit security

$\underline{5 \text { days }}$ 
Step (37) at FIS Facility

- Turnaround time at fuel disposition facility

2 days

- Total time for intermodal (heavy-haul truck to rail)

spent fuel shipment with two rail casks

27 days

\subsubsection{Estimated Campaign Duration}

Based on 2 rail casks turned around in an average of 4 weeks, the total number of fuel assemblies per shipment equals 14 per 4-week cycle. Therefore, time required to ship one-third of a PWR reactor core of 72 bundles is about 139 days, including cask maintenance and testing periods.

\subsubsection{Barge to Rail Transport Scenario}

As an alternative to use of the heavy-haul truck mode, assume barge to rail intermodal transport of one-third PWR reactor core with 2 rail casks carrying 7 fuel assemblies in each cask.

\subsubsection{Sunmary of Barge/Rail Scenario}

$\begin{array}{lll}\text { Steps } 1 \text { to } 2 & \text { Cask loaded on train } & 1.5 \text { days } \\ \text { Steps } 2 \text { to } 9 & \begin{array}{l}\text { Cask transported to intermodal } \\ \text { transfer point barge location }\end{array} & 1 \text { day } \\ \text { Step } 10 & \text { Cask transferred to barge } & 1.5 \text { days } \\ \text { Steps } 11 \text { to } 12 & \text { Cask transported to reactor site by barge } & 5 \text { days } \\ \text { Steps } 13 \text { to } 17 & \text { Cask unloaded at reactor site onto dollies } & 2 \text { days } \\ \text { Steps } 14 \text { to } 17 & \text { Cask transferred to fuel pool and } & 4 \text { days } \\ \text { Steps } 17 \text { to } 25 & \text { Cask returned to barge and loaded } & 2 \text { days } \\ \text { Steps } 25 \text { to } 27 & \text { Cask transported to intermodal } & \\ \text { transfer point by barge } & \text { Cask unloaded from barge to train } \\ \text { Step } 27 & \text { Cask transported to Fis site by train } & 5 \text { days } \\ \text { Steps } 27 \text { to } 37 & \text { Casks unloaded and placed in storage facility } & 2 \text { days } \\ \text { Step } 37 & & \end{array}$

Total 26 days




\subsubsection{Estimated Campaign Duration}

The total number of fuel assemblies per shipment is $2 \times 7$ or 14 per 26-day cycle. Therefore, the time to ship 72 assemblies is 134 days.

6.1.3 Barge to Heavy-Haul Truck Transport Scenario

For the third scenario, assume the barge to heavy-haul truck transport of 72 PWR fuel assemblies per year in 2 rail casks.

6.1.3.1 Summary of Barge to Heavy-Haul Truck Scenario

Steps 1 to $2 \quad$ Cask loaded on truck

1 day

Steps 2 to 9 Cask transported to intermodal transfer point (barge location)

Step 10

Cask loaded on barge from truck (2 casks)

Step 11 to 12

Cask transported to reactor site by barge

5 days

Steps 13 to 17 Cask unloaded at reactor site onto

rubber-tired dollies

Steps 14 to 17 Cask transferred to fuel pool and loaded

with spent fuel

Steps 17 to 25 Cask returned to barge and loaded

2 days

Steps 25 to 27

Cask transported to intermodal transfer

point by barge

5 days

Step 27

Cask unloaded from barge to heavy-haul truck

2 days

Steps 27 to 37

Cask transported to FIS site by heavy-haul truck

1 day

Step 37

Cask unloaded and placed in federal interim storage

Total

27 days

\subsubsection{Estimated Campaign Duration}

The total number of fuel assemblies per shipment is 4 per 27 -day cycle. Therefore, the time to ship 72 assemblies is 139 days, assuming 2 casks and one barge. Adding additional casks and barges would reduce the time required to ship the 72 fuel assemblies. 


\subsubsection{Summary of Spent Fuel Shipment Scenario Discussion}

The turnaround time for a rail cask shipped by the heavy-haul truck to rail intermodal transport scenario is estimated to be about 28 days. For the barge to rail scenario, the turnaround time is estimated to be about 26 days, and for the barge to heavy-haul truck scenario, the turnaround time is estimated to be about 27 days. On this basis, there was not found to be a significant difference in turnaround time between the different transport scenarios. Thus, a decision to be reached for the best scenario option for a specific spent fuel shipment could not be made on the basis of the turnaround time. The decision would have to be nade on the basis of total cost and availability.

\subsection{TRANSPORT SYSTEMS}

The choice of intermodal transport mode for a particular intermodal transport sequence (ITS) would be made largely on the basis of economics and the convenience of the situation.

A comparison of the different types of casks, the vehicle weight, the number of assemblies carried, and the transport capacity is summarized in Table 6.1. Three general types of casks are listed, which are representative of rail, truck/rail, and transport/storage casks. They have transport capacities of 3.25 to 5.4 MTU of fuel. The gross vehicle weight per metric ton of uranium is also shown. All of the casks have about the same amount of fuel shipped per vehicle ton.

Heavy-haul trucks can be considered for use in providing a connecting link for movement of rail casks between reactor loading points and railheads close to the reactor plant. However, road weight limitations could seriously limit shipments of this type.

Railroads have proposed that special trains be used to haul spent fuel. The advantages of special trains may include shorter transit time and crews that are expert in handling spent fuel. The major disadvantage may be increased cost. Because of economic considerations, larger casks, which provide greater capacity per unit cask weight, may be preferred for long distance shipments. 
TABLE 6.1. Transport Cask Comparison

\begin{tabular}{|c|c|c|c|c|c|c|c|}
\hline \multirow[b]{2}{*}{ Mode } & \multicolumn{2}{|c|}{$\begin{array}{c}\text { Gross Vehicle } \\
\text { Weight }\end{array}$} & \multicolumn{2}{|c|}{ Cask weight } & \multirow{2}{*}{$\frac{\text { Assemblies }}{\text { PWR/BWR }}$} & \multirow{2}{*}{$\begin{array}{l}\text { Mg U in } \\
\text { Cask }\end{array}$} & \multirow{2}{*}{$\begin{array}{c}\text { Gross } \\
\text { Vehicle } \\
\mathrm{kg} \text { per Mg U }\end{array}$} \\
\hline & $\mathrm{kg}$ & (1b) & $\mathrm{kg}$ & (1b) & & & \\
\hline \multicolumn{8}{|l|}{ Truck/Rail } \\
\hline Intermodal-IF-300 & 120,000 & 264,000 & 63,500 & 140,000 & $7 / 18$ & 3.25 & 37,000 \\
\hline \multicolumn{8}{|l|}{ Rail } \\
\hline NLI $10 / 24$ & 160,000 & 350,000 & 90,700 & $(200,000)$ & $10 / 24$ & 4.52 & 35,000 \\
\hline$T N-12$ & 147,000 & $(320,000)$ & 105,000 & $(230,000)$ & $12 / 32$ & 5.42 & 27,000 \\
\hline \multicolumn{8}{|l|}{ Transport/Storage } \\
\hline GNS-Proposed Cask & 160,000 & $(350,000)$ & 96,200 & $(212,000)$ & $9 / 25$ & 4.40 & 36,000 \\
\hline
\end{tabular}

\subsection{CASK HANDLING}

The unloading characteristics for the rail type of casks at a spent fuel repository is shown in Table 6.2.

A major advantage of the larger rail casks is illustrated in the table. The larger casks have a distinct improvement in potential operator exposure per MT $U$ of fuel unloaded. Improvements are realized during the loading operation and are of importance from the standpoint of considerations to keep doses to workers and the public as low as reasonably achievable (ALARA).

Two major areas of concern for most plants are the timely scheduling of the casks and the movement of these large and heavy casks in the plant. Although most of the newer large capacity plants are and have been designed to use a rail cask, some of these plants may even experience problems with the larger rail casks planned.

Decontamination of the cask exterior before shipping is a major source of operator radiation exposure and is also very time-consuming. Contamination on the cask surface occurs when the cask is placed in a contaminated pool. Smooth and regular stainless steel cask surfaces are preferred. If the cask surface is finned for heat dissipation purposes, a contamination barrier is needed to isolate the cask from the pool water. The cask should have provisions for 
TABLE 6.2.
Spent Fuel Cask Turnaround Cycle (cask
unloading at spent fuel repository)

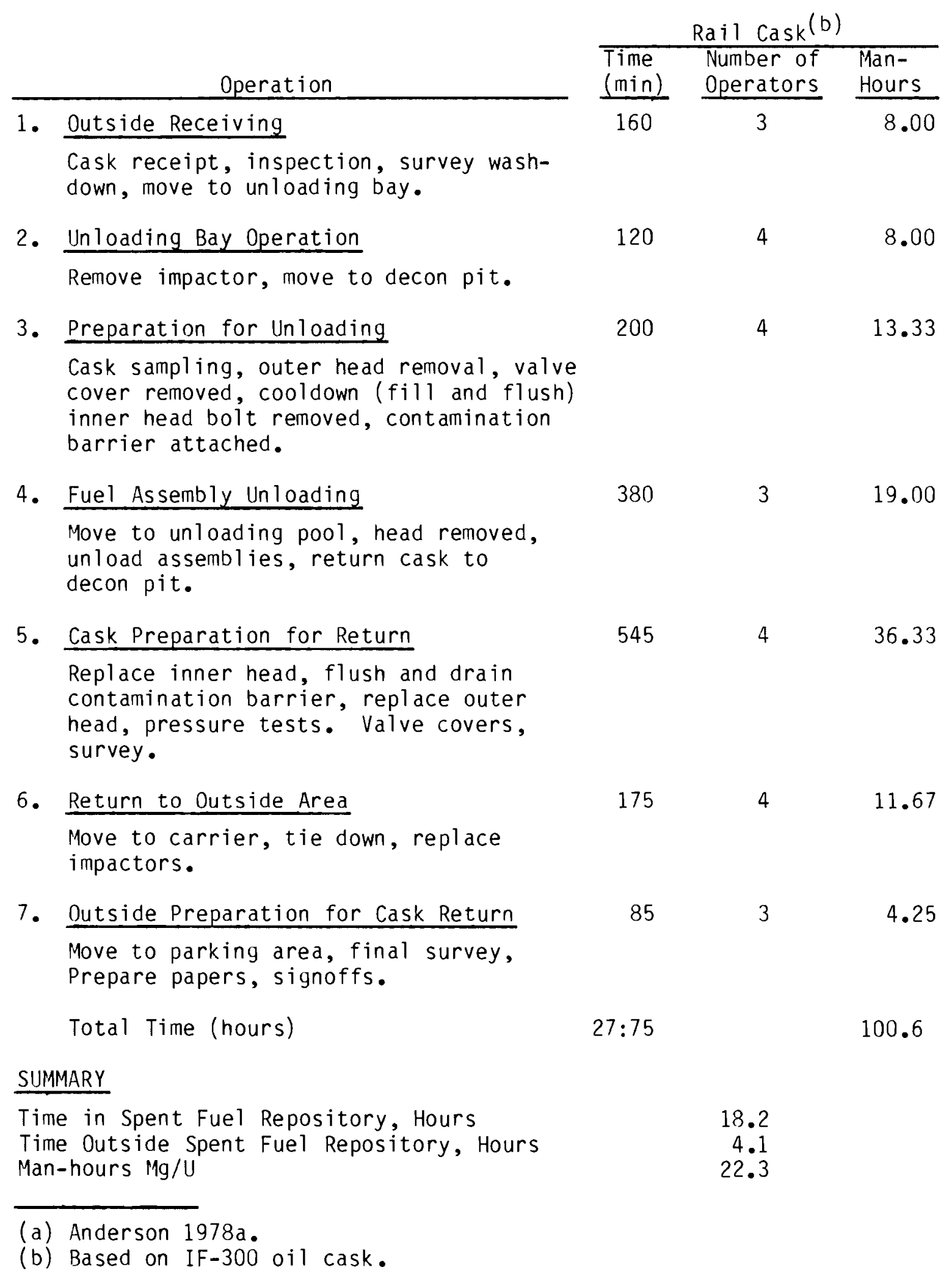


attaching such a contamination barrier. The contamination barrier may be plastic or metal; however, such barriers are expected to add to the cost of operations and to require considerable storage space.

Cask handling can be simplified if crud trapped in fuel baskets, cask internals, and in the fuel cavity of the cask can be eliminated. Dedicated casks (i.e., casks that would transport only BWR or PWR fuel) can decrease crud problems by eliminating the need for fuel basket changeout. If basket changeout is the accepted mode of operation, basket removal and decontamination could be done in a separate cask maintenance facility dedicated to this type of maintenance.

Operations associated with positioning the closure head or sealing the cavity are difficult on large rail casks. Operational difficulties can result from tight closure-head clearances and gasket problems. The transport vehicle may become contaminated during loading or unloading, and it may be necessary to wash down road dirt on the vehicle and the cask.

A 100+-ton crane is required for actual lifts of heavy rail casks. Ideally, cask lifting should be the sole purpose of this heavy equipment.

Experience has shown that different yokes are required for each cask. Similarly, different grapples are required for each fuel type. In certain circumstances, standard grapples will not remove the fuel from a given cask, thereby requiring modifications or the acquisition of additional grapples. These problems are unique to a facility that must accommodate all fuel and cask types. From an operational standpoint, it is time-consuming to marshal specialized tooling for each unique combination of fuel and cask. 


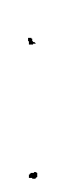




\subsection{INTERMODAL EQUIPMENT AND RESEARCH NEEDS}

New or modified equipment needed to facilitate the intermodal transport of spent fuel (using the systems described in this study) is discussed in this section. Two categories of equipment are covered: 1) transport equipment used to move the cask from one location to another, and 2) transfer equipment, such as cranes, used to move the cask locally. Further research needed to implement intermodal transport is also described.

\subsection{INTERMODAL EQUIPMENT NEEDS}

Tables 7.1, 7.2, and 7.3 list the equipment that is available and the equipment that is needed to accomplish transportation and transfer between modes for each intermodal transport sequence (ITS) element for the three baseline scenarios. The major pieces of equipment needed to affect intermodal transport and transfer of spent fuel casks are listed below for each scenario:

1. Heavy-Haul Truck to Rail Scenario

- rail cask for long-cooled fuel

- transport/storage casks

- cradle or load-spreading base to support the cask during transport

- cask lifting device (may be designed to travel with the cask)

- roll-on, roll-off equipment for transfer from rail car to heavyhaul truck

- cask handling equipment at the intermodal transfer location

- heavy-haul truck trailers for casks other than the IF-300

- air pallets (if crane availability is not adequate)

- tie-down equipment.

2. Barge to Rail Scenario

- transport/storage cask

- rail cask for long-cooled fuel

- cradle to support the cask during transport 
TABLE 7.1. Equipment Availability for the Heavy-Haul Truck to Rail Scenario

\begin{tabular}{|c|c|c|c|}
\hline & Equipment Required & $\begin{array}{l}\text { Equipment } \\
\text { Availability }\end{array}$ & Corments \\
\hline & 1. Rail Cask & Yes & $\begin{array}{l}\text { Existing casks not sufficient, new shipping or shipping/ } \\
\text { storage casks will be needed }\end{array}$ \\
\hline 2. & 2. Rail Car and Locomotive & Yes & \\
\hline & 3. Rail Cask for Long-Cooled Fuel & No & Casks for long-cooled fuel are currently under development \\
\hline & 4. Transport/Storage Cask & No & \\
\hline & 5. Heavy-Haul Truck Trailers (IF 300) & Yes & \\
\hline & 5. Heavy-Haul Truck Tractor & Yes & \\
\hline 7. & $\begin{array}{l}\text { - Cask Skids to Support Cask on } \\
\text { Transport Equi pment }\end{array}$ & No & \\
\hline & $\begin{array}{l}\text { Cask Lifting Device (short lifts, } \\
\text { i.e., between floor and truck } \\
\text { trailer) to travel with cask. }\end{array}$ & No & \\
\hline 9. & - Crane and Auxiliary Equipment & Yes & \\
\hline 10 . & D. Air Pallet & No & No information on air pallets \\
\hline 11 . & 1. Radiation Mnitoring Equi ment & Yes & \\
\hline 12. & 2. Cask Handling Equipment & $\mathrm{No}$ & \\
\hline 13. & 3. Tie-down Equipment & No & \\
\hline 14. & 1. Decontamination Equipment & Yes & \\
\hline 15. & - Fuel Handl ing Equipment & Yes & \\
\hline & $\begin{array}{l}\text { Roll-on, Roll-off Equipment IF-300 } \\
\text { Other Casks }\end{array}$ & $\begin{array}{l}\text { Yes } \\
\text { No }\end{array}$ & \\
\hline
\end{tabular}


TABLE 7.2. Equipment Availability for the Barge to Rail Scenario

Equipment Required

1. Rail Cask

2. Rail Car (IF-300)

(Other Casks)

3. Locamt ive

4. Rail Cask for Long-Cooled Fuel

6. Cask Skids

7. Cask Lifting Device

8. Crane and Auxiliary Equiprent

9. Air Pallet

10. Parge

11. Small Ship

12. Radiation Monitoring Equipment

13. Cask Handling Equipment

14. Tie-down Equipment

15. Decontamination Equipment

16. Fuel Handl ing Equi prent

17. Roll-on, Roll-off Equipment

IF-300

Other Casks
Equipment

Availability

Yes

Existing casks not sufficient, new shipping or shipping/ storage casks will be needed

Yes

No

Yes

No

No

$\mathrm{No}$

Yes

No

No information on air pallets

Yes

Dedicated barges may not be available
No

Yes

No

No

Yes

Yes

Yes

No 
TABLE 7.3. Equipment Availability for the Barge to Heavy-Haul Truck Scenario

\section{Equipnent Required}

1. Rail Cask

2. Transport/Storage Casks

3. Heavy-haul Truck Trailers

$$
\text { (IF-300) }
$$

(Other Casks)

4. Heavy-haul Truck Tractor

5. Cask Skids for Land and water Transport

6. Cask Lifting Device

7. Crane and Auxiliary Equiprent

8. Air Pallet

9. Barge and Equiprent

10. Small Ship

11. Radiation Menitoring Equiprent

12. Cask Handling Equipment

13. Tie-down Equi pment

14. Decontamination Equipment

15. Fuel Handl ing Equi pment

16. Load Spreading Equipment for Barge

$$
\text { IF-300 }
$$

Other Casks
Equipment Availability

Yes

Existing casks not sufficient, new shipping or shipping/ storage casks will be needed

No

Yes

No

Yes

No

Skid needed to distribute loads on barge

No Equipment needed to lift cask onto barye

Yes

No infomation available on air pallets

Yes

Dedicated barge may not be available

No

Yes

№

No

Yes

Yes

Yes

No 
- cask lifting device may be designed to travel with the cask

- barge or small transport ship for water transport

- cask handling equipment at intermodal transfer location

- roll-on, roll-off equipment

- dedicated barge

- rail cars for casks other than IF-300

- air pallet for rail cask movement

- tie-down equipment.

3. Barge to Heavy-Haul Truck Scenario

- transport storage cask

- rail cask for long-cooled fuel

- cradle or skid to support cask during land and water travel

- cask lifting device from truck to barge

- barge and equipment modified to take equipment loads

- small ship

- load spreading device for cask on the barge

- cask handling equipment at intermodal transfer location

- heavy-haul truck trailer for casks other than IF-300

- air pallets

- tie-down equipment.

The important items and estimated lead times for procurement needed to effect intermodal fuel transport for the condition of this study are shown in Table 7.4.

\subsection{RESEARCH NEENS}

To implement intermodal transport of spent fuel, further research is needed in several areas:

- Further work should be done to determine specifically how spent fuel would be transported and which routes and modes are preferable for given origin/destination plans. 
TABLE 7.4. Intermodal Equipment Procurement Lead Times

\begin{tabular}{|c|c|}
\hline Equi pment & $\begin{array}{l}\text { Estimated Lead } \\
\text { Time to Procure } \\
\end{array}$ \\
\hline Dedicated Barge & 3 years \\
\hline Dedicated Small Ship & 5 years \\
\hline Equipment skids & 1 year \\
\hline Cask Lifting Device & 1 year \\
\hline Rail Cars & 1 year \\
\hline $\begin{array}{l}\text { Cask Handling Equipment at } \\
\text { Intermodal Transfer Location }\end{array}$ & 6 months \\
\hline $\begin{array}{l}\text { Heavy-Haul Truck Trailer for } \\
\text { Casks other than IF- } 300\end{array}$ & 6 months \\
\hline Air Pallets & 1 year \\
\hline Roll-on, Roll-off Equipment & 1 year \\
\hline Transport/Storage Cask & 7 years \\
\hline Rail Cask for Long-Cooled Fuel & 7 years \\
\hline Tie-Down Equipment & 1 year \\
\hline
\end{tabular}

- Alternative methods of intermodal transport should be further reviewed to determine their feasibility.

- Intermodal transfer from rail to heavy-haul truck should be considered in greater detail for casks other than the IF-300, which was designed for intermodal capability.

- A detailed assessment of heavy-haul land vehicles to move the cask over relatively short distances should be provided.

- Availability of rail casks should be investigated. (If transport/storage casks are not feasible).

- Cost of the various modes should be researched.

- Availability of dedicated barges and small commercial ships for fuel transport should be investigated. 
- Cask availability should be researched based on specific needs and requirements to determine the need for new cask procurement.

- A continued emphasis on developing casks to handle dry-cooled fuel is recommended.

- The size of barges and small transport ships to be used and the number of casks transported per barge should be investigated.

- Use of transport/storage casks should be researched.

- The economics of intermodal shipment should be studied. 



\subsection{CONCLUSIONS AND RECOMMENDATIONS}

Existing rail and marine systems can provide a transport base for the intermodal movement of spent fuel to federal interim storage (FIS) facilities with some modifications and provisions for new equipment. Table 8.1 shows a summary of the equipment needed to entirely facilitate intermodal shipments of spent fuel for the three baseline scenarios. The implementation of intermodal spent fuel transport will require that this equipment be available for the particular scenario that is used. New equipment and needed modifications are described in Section 7 of this report.

There is no significant difference in the times involved for shipment of the alternative intermodal transport modes. The choice of mode selected for intermodal transport for a particular intermodal transport sequence (ITS) would be made on the basis of economics, and the convenience of the situation. Dedicated barges or small ships are preferred to commercial vessels because the estimated ocean transit-time is probably 50\% greater for the regular commercial vessel.

TABLE 8.1. Intermodal Equipment Requirements(a)

\begin{tabular}{|c|c|c|c|}
\hline \multirow[b]{2}{*}{ Item } & \multicolumn{3}{|c|}{ Scenario } \\
\hline & HH Truck/Rail & Barge/RaiT & Barge/HH Truck \\
\hline Transport/Storage Casks & $x$ & $x$ & $x$ \\
\hline Rail Cask for Long-Cooled Fuel & $x$ & $x$ & $x$ \\
\hline Equipinent Skid (cradle) & $x$ & $x$ & $x$ \\
\hline Cask Lifting Device & $x$ & $x$ & $x$ \\
\hline Dedicated Transport Barge & & $x$ & $x$ \\
\hline Dedicated Small Ship & & $x$ & $x$ \\
\hline Cask Handling Equipment & $x$ & $x$ & $x$ \\
\hline Heavy-Haul Truck Trailers & $x$ & & $x$ \\
\hline Air Pallets & $x$ & $x$ & $x$ \\
\hline Tie-down Equipment & $x$ & $x$ & $x$ \\
\hline
\end{tabular}

(a) Summarized from data in Tables $7.1,7.2$, and 7.3 . 
Some needed land transportation support, loading and unloading equipment does not currently exist. Sufficient shipping casks for future United States spent fuel shipments are not available at this time, and additional casks will be needed (DOE 1978a). Spent fuel casks are currently being fabricated in Europe and Asia (DOE 1978c). Industrial capabilities may be adequate to fabricate casks when needed for transport of LWR fuel in the United States.

Procurement of dedicated barges or small ships should be started early enough in the planning stage so that shipping will be available at the time it is needed. Since sufficient casks may not be available when required, procurement should be implemented with an allowance for lead times of 18 to 24 months for existing licensed casks and from 6 to 8 years for a cask yet to be licensed. 


\section{REFERENCES}

Anderson, R. T. 1978a. Studies and Research Concerning BNFP--Light Water Reactor Spent Fuel Transportation Systems. AGNS-1040-1.3-47, Allied-General Nuclear Services, Barnwel1, South Carolina.

Anderson, R. T. 1978b. Studies and Research Concerning BNFP--Topical Report of the Operational As sessment of the Transnuclear TN $8 / 9$ Spent Fuel Cask. AGNS-1040-1.1-31, Allied General Nuclear Services, Barnwel1, South Carolina.

Anderson, R. T., and R. Jones. 1980. Transportation of Radioactive Material by Water. AGNS-35900-1.4-115, All ied-General Nuclear Services, Barnwel1, South Carolina.

Aoki, S., and K. Ikeda. 1978. "Licensing Experiences, Risk Assessment, Demonstration Test on Nuclear Fuel Packages and Design Criteria for Sea-Going Vessels Carrying Spent Fuel in Japan." In Proceedings of the Fifth International Symposium on Packaging and Transportation of Radioactive Materials, pp. 125-127, Las Vegas, Nevada.

Atomic Industrial Forum. 1978. A Generic Assessment of Barge Transportation of Spent Nuclear Fuel. AIF/NESP-014.

Benson, W. C. 1974. "The Development of High Strength, Low Weight SemiTrailers for Transportation of Nuclear Fuel." In Proceedings of the Fourth International Symposium on Packaging and Transportation of Radioactive Materials. CONF-740901-Pl, Miami Beach, Florida.

Best, R. E., et al. 1977. Capabilities of U.S. Domestic Transportation Systems for the Shipment of Radioactive Wastes. NACC-7715, Nuclear Assurance Corporation, Atlanta, Georgia.

Code of Federal Regulations (CFR 1975), Title 49. Parts 170-179 (49 CFR 170179), U.S. Government Printing Office, Washington, D.C.

Code of Federal Regulations (CFR 1976), Title 10. Part 71 (10 CFR 71), U.S. Government Printing Office, Washington, D.C.

Code of Federal Regulations (CFR 1979), Title 46. U.S. Coast Guard. U.S. Government Printing Office, Washington, D.C.

Daling, P. M. and R. L. Engel. 1983. Analysis of Near Term Spent Fuel Transportation Hardware Requirements and Transportation Costs. PNL-4575, Pacific Northwest Laboratory, Richland, Washington.

Dierkes, P., et al. 1980. "Transport Casks Help Solve Fuel Interim Storage Problems." Nuclear Engineering International.

General Electric. 1973. Instructions-IF 300 Irradiated Fuel Shipping Cask. GEI-92817, Nuclear Energy Division, General Electric Company. 
International Atomic Energy Agency (IAEA). 1973. Regulations for the Safe Transport of Radioactive Materials. 1973 Revised Edition, Safety Series No. 6, Vienna, Austria.

Kavanaugh, M. R., and S. Shimoyama. 1976. "Irradiated Nuclear Fuel Transport from Japan to Europe." In Proceedings of the First Pacific Basin Conference on Nuclear Power Development and the Fuel Cycle. Honolulu, Hawaii.

LeNoc and Bertonneu. 1977. "The Irradiated Fuel Transport and Handling System Used in EDF Nuclear Installations." In Proceedings of the International Conference on Nuclear Power and Its Fuel Cycle. AIEA-CN-36/240, Salzburg, Austria.

Loscutoff, W. V., et al. 1977. A Safety and Economic Study of Special Trains for Shipment of Spent Fuel. BNWL-2263. Pacific Northwest Laboratory, Richland, washington.

Mensah, T. A. 1972. "Regulations Laid Down by the International Convention on the Safety of Life at Sea (1960) and the IMCO Code of Practice for Maritime Transport of Nuclear Material." Presented at the Symposium on Maritime Carriage of Nuclear Materials, Stockholm, Sweden.

Mori, Y. 1978. "Motor Vessel HINOURA MARU - A Specialized Carrier for Spent Fuel." In Proceedings of the Fifth International Symposium on Packaging and Transportation of Radioactive Materials, pp. 150-154, Las Vegas, Nevada.

Nuclear Waste Policy Act of 1982. 1982. Congressional Record - U.S. House of Representatives. pp. H-10525-H-10544.

Nuclear Waste News. January 28, 1982. p. 15. "D0E Awards $\$ 780,000$ to Build Dry Storage Containers." REA 2023 Cask.

Standard Handbook for Mechanical Engineers, 75th ed. 1967. T. Baumeister and L. S. Marks, eds., McGraw-Hil1, New York, New York.

U.S. Atomic Energy Commission (USAEC). 1972. Environmental Survey of Transportation of Radioactive Materials to and from Nuclear Power PTants. USAEC Report WASH-1238 (NUREG-75/038), Washington, D.C.

U.S. Department of Energy (DOE). 1977. "U.S. Spent Fuel Policy." DOE Press Release, D0E/SR-77-30 News Release, Washington, D.C.

U.S. Department of Energy (DOE). 1978a. Draft Environmental Impact Statement - Storage of U.S. Spent Power Reactor Fuel. D0E/EIS-0015-D, Washington, D.C.

U.S. Department of Energy (DOE) . 1978b. Analytical Methodology and Facility Description - Spent Fuel Policy. DOE/ET-0045, Washington, D.C. 
U.S. Department of Energy (DOE). 1978C. Draft Environmental Impact Statement - Storage of Foreign Spent Power Reactor Fuel. D0E/EIS-0040-D, Washington, D.C.

U.S. Department of Energy (DOE) . 1979. Spent Fuel Storage Requirements - The Need for Away-From-Reactor Storage. DOE/ET-0075, Washington, D.C.

U.S. Department of Energy (DOE) . 1983. Spent Fuel Storage Requirements. DOE/RL-83-1, U.S. Department of Energy, Richland Operations Office, Richland, Washington.

U.S. Department of Transportation (DOT) and Atomic Energy Commission (AEC) . 1973. "Memorandum of Understanding Between DOT and AEC for Regulation of Safety in the Transportation of Radioactive Materials Under the Jurisdiction of DOT and NRC." 1 CCH NuC. Reg. Rep. 1009:2028. 38 F.R. 8466, New York, New York.

Winsor, G. H., D. W. Faletti and J. G. DeSteese. 1980. Opportunities to Increase the Productivity of Spent Fuel Shipping Casks in the U.S. PNL-3017, Pacific Northwest Laboratory, Richland, Washington.

Washington Public Power Supply System (WPPSS). WPPSS Nuclear Project No. 2, Final Safety Analysis Report. Vol. 16. Richland, Washington. 


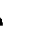

. 
No. of

Copies

OFFSITE

J. H. Carlson

Nuclear Waste Policy Act Project office

U.S. Department of Energy NE-43

Washington, DC 20545

K. A. Klein

Nuclear Waste Policy Act

Project Office

U.S. Department of Energy

$N E-43$

Washington, DC 20545

M. J. Lawrence

Nuclear Waste Policy Act Project Office

U.S. Department of Energy

$\mathrm{NE}-43$

Washington, DC 20545

S. P. Schneider

Nuclear Waste Policy Act

Project Office

U.S. Department of Energy

NE-43

Washington, DC 20545

R. D. Nelson

U.S. Department of Energy

DP 221-MS 4B026

1000 Independence Ave., S.W.

Washington, DC 20585

Don Veith

U.S. Department of Energy

P.0. Box 14100

Las Vegas, NV 89114
No. of

Copies
U.S. Nuclear Regulatory

Commission

Spent Fuel Storage Installation

Division of Fuel Cycle and

Material Safety

Washington, DC 20555

2 U.S. Nuclear Regulatory Commission

Office of Nuclear Materials Safety and Safeguards

Washington, DC 20555

ATTN: N. H. Davison

J. Roberts

D. Reisenweaver

U.S. Nuclear Regulatory Commission

Office of Nuclear Regulatory Research

MS $5650 \mathrm{NL}$.

Washington, DC 20555

Connor Matthews

U.S. Department of Energy

Oak Ridge Operations Office

P.0. Box E

Oak Ridge, TN 37830

R. Kunita

Carolina Power \& Light Co. P.0. Box 1551

Raleigh, NC 27602

D. G. Ebenback

ChemNuclear Systems, Inc.

P.0. Box 1866

Bellevue, WA 98009 
No. of Copies

N. Fuhrman

Combustion Engineering, Inc.

C-E Power Systems

Windsor, CT 06095

G. P. Wagner

Commonwealth Edison

Station Nuclear Engineering

Department

P.0. Box 767

Chicago, IL 60690

F. W. Buckman

Consumers Power Company

1945 W. Parnall Road

Jackson, MI 49201

R. Rasmussen

Duke Power Co.

P.0. Box 33189

Charlotte, NC 28242

R. Y. Lowrey

DOE Alburquerque Operations Office

P.0. Box 5400

4lbuquerque, NM 87115

4 Sandia National Laboratory

Transportation Technology Center

Albuquerque, NM 87185

ATTN: G. C. Allen

R. M. Jefferson

R. B. Pope

C. G. Shirley

R. Stanford

Edison Electric Institute

11119 th Street, N.W.

Washington, DC 20036

2 Electric Power Research Institute

P.0. Box 10412

Palo Alto, CA 94304

ATTN: R. F. Williams

R. W. Lambert
No. of

Copies

R. Silva

Florida Power \& Light Co.

P.0. Box 013100

Miami, FL 33101

D. W. Ketchen

General Atomic

P.0. Box 608

San Diego, CA 92112

E. E. Voiland

General Electric Company

Morris Operation

Morris, IL 60450

B. Handly

Houston Lighting \& Power Co.

Nuclear Fuels, Baybrook

P.0. Box 1700

Houston, TX 77001

2 E. R. Johnson Associates, Inc.

11702 Bowman Green Drive

Reston, VA 22090

ATTN: E. R. Johnson

J. A. McBride

J. H. Garrity

Maine Yankee Atoinic Power Co.

Edison Drive

Augusta, ME 04336

2 Northeast Utilities Service Co.

P.0. Box 270

Hartford, CT 06101

ATTN: R. Calabro

M. T. Pitek

2 Nuclear Assurance Corporation

24 Executive Park West

Atlanta, GA 30329

ATTN: J. Houston

J. Viebrock

B. D. Guilbeault

NUS Corporation

910 Clopper Road

Gaithersburg, MO 20878 
No. of

Copies

R. Rogan

Portland General Electric

131 S.W. Salmon Street

Portland, OR 97204

2 Tennessee Valley Authority

404 Krystal Building

Chattanooga, TN 37402

ATTN: J. B. Moegling

H. B. Brooks

2 Transnuclear

1 N. Broadway

White Plains, NY 10601

ATTN: W. R. Teer

J. Mangusi

D. C. Young

Virginia Electric \& Power Co.

P.0. Box 2666

Richmond, VA 23261

2 Westinghouse Electric Corp.

P.0. Box 708

Mercury, NV 89023

ATTN: J. C. Dobbins

A. R. Hakl

R. J. Bahorich

Westinghouse-Pittsburgh

Advanced Energy Systems Div.

P.0. Box 10864

Pittsburgh, PA 15236

27 DOE Technical Information Center

\section{ONSITE}

3 DOE Richland Operations Office

P. A. Craig

H. E. Ransom

J. J. Schreiber
No. of

Copies

Human Affairs Research Centër

T. Overcast

45

Pacific Northwest Laboratory

W. B. Andrews

N. M. Burleigh

T. D. Chikalla

B. M. Cole

P. M. Daling

H. K. Elder (10)

R. M. Fleischman

J. F. Fletcher

A. L. Frankl in

D. L. Gale

R. J. Hall

D. K. Kreid

G. M. Holter

W. S. Kelly

R. C. Liikala

H. D. Massey

P. N. MCDuffie

G. W. MCNair

J. L. NCEl roy

J. F. Nesbitt

D. F. Newman

D. R. Payson

R. E. Rhoads

K. J. Schneider

M. J. Sherbin

R. I. Sinith

W. R. Wiley

L. D. Williams

J. R. Young

Publishing Coordination (2)

Technical Information (5) 
